\title{
Sustentabilidade socioambiental e diálogo de saberes: \\ o Pantanal Mato-grossense e seu espaço vernáculo como referência
}

\section{Socio-Environmental Sustainability and knowledge dialog: Pantanal Mato-grossense and its space of a reference}

\author{
Antonio M. N. CASTELNOU* \\ Dimas FLORIANI ${ }^{* *}$ \\ Icléia A. de VARGAS ${ }^{* * *}$ \\ Janise Bruno DIAS ${ }^{* * * * *}$
}

\begin{abstract}
RESUMO
Este artigo tem como base a discussão sobre a crise ambiental, a qual culminou na crise do modelo econômico vigente e nos limites da ciência moderna, levando à busca e construção interdisciplinar de uma nova racionalidade: a racionalidade ambiental. Fundamentando-se basicamente nos estudos de Enrique Leff, pretende apresentar algumas considerações quanto à questão da sustentabilidade socioambiental no Pantanal a partir da possibilidade de um diálogo de saberes.

Palavras-chave: desenvolvimento sustentável, meio ambiente, saber ambiental.
\end{abstract}

\begin{abstract}
This article is based on the environmental crisis discussion, which culminated in the effective economical model crisis and in the modern science limits, taking to the search and construction of a new rationality: the environmental rationality. This paper is based upon Enrique Leff"'s studies, it intends to present some considerations related to the subject of the Pantanal socio-environmental sustainable development starting from the possibility of a knowledge dialogue.

Key-words: sustainable development, environment, environmental knowledge.
\end{abstract}

\footnotetext{
* Arquiteto e Engenheiro Civil, Mestre em Tecnologia do Ambiente Construído, pela Escola de Engenharia de São Carlos da Universidade de São Paulo - EESC/ USP e Doutorando em Meio Ambiente e Desenvolvimento pela Universidade Federal do Paraná - UFPR, em Curitiba. <castelnou@ yahoo.com>

Doutor em Sociologia, Professor Titular do Departamento de Ciências Sociais e do Doutorado em Meio Ambiente e Desenvolvimento da Universidade Federal do Paraná - UFPR, em Curitiba.<floriani@ufpr.br>

Geógrafa, Mestre em Educação, pela Universidade Federal de Mato Grosso do Sul - UFMS e Doutoranda em Meio Ambiente e Desenvolvimento pela Universidade Federal do Paraná - UFPR, em Curitiba.<iavargas@sulbbs.com>

***** Bióloga, Mestre em Geografia, pela Universidade Federal de Minas Gerais - UFMG e Doutoranda em Meio Ambiente e Desenvolvimento pela Universidade Federal do Paraná - UFPR, em Curitiba. <janise@uol.com.br>
} 
CASTELNOU, A. M. N. et al. Sustentabilidade socioambiental e diálogo de...

\section{Introdução}

A problemática ambiental, nos últimos tempos, vem ocupando um importante papel nas discussões sobre os rumos da economia e da política internacional. Isso tem se refletido em todas as esferas da vida contemporânea, encontrando rebatimento na maioria das atividades humanas. Desde que as preocupações ecológicas passaram a marcar o panorama mundial - nos anos 60 e 70 do século passado - permeiam as nossas reflexões os problemas decorrentes de uma prática fundamentada essencialmente na idéia de que a natureza é fonte inesgotável de recursos. O logocentrismo, a racionalidade tecnológica e o desequilíbrio dos crescimentos econômico e populacional conduziram a uma crise que hoje aflige a humanidade, promovendo inúmeros questionamentos sobre todas as formas de ação da sociedade na natureza, traduzindo-se, inclusive, em reflexões e interferências sobre as formas de produção do espaço engendradas pelas sociedades humanas. Como signos dessas mudanças de representação do conhecimento emergem novos resgates cognitivos sobre o ser (identidade) e o fazer (tecnologias) das culturas abafadas pela modernidade impositiva.

Assim, a partir da segunda metade do século XX, arquitetos, historiadores de arte, antropólogos, sociólogos e demais cientistas, voltaram seus olhares para a chamada arquitetura vernacular, ou seja, aquela produzida por indivíduos que não passaram por uma academia ou tiveram alguma formação regular, de acordo com os cânones eruditos. Situam-se aí os povos primitivos, os indígenas, os camponeses e demais pessoas ou comunidades situadas à margem do processo de produção oficial. Esse interesse pela construção vernácula em ambientes urbanos ou rurais, refletiu-se inicialmente por meio de publicações, como Native genius in anonymous architecture (1957), de Sibyl Moholy-Nagy, e Design for a real world (1967), de Victor Papanek; e exposições, como a intitulada Architecture without architects, organizada por Bernard Rudofsky no Museu de Arte Moderna de Nova York, em 1963, para depois promover um intenso trabalho de investigação e análise.
Passou-se a perceber que o conhecimento, os saberes e as práticas dessas comunidades - antes vistas como rudimentares ou mesmo arcaicas - possuíam elementos de valiosa contribuição para a discussão ambiental. Esta se intensificava mundialmente através da divulgação de vários estudos como Silent Spring (1962), de Rachel Carson; The Population Bomb (1967), de Paul Ehrlich; ou The Limits of Growth (1972), de D. Meadows; culminando com a realização da Conferência das Nações Unidas sobre o Meio Ambiente Humano (Estocolmo, 1972), a qual propunha o desenvolvimento de uma educação ambiental fundamentada em uma visão holística da realidade e nos métodos da interdisciplinaridade, os quais começavam a ser debatidos em todo o mundo, inclusive na América Latina e no Brasil.

As contingências que marcaram o cenário mundial nas décadas que sucederam a Segunda Guerra Mundial (1939/ 45), tais como a explosão demográfica, os inúmeros movimentos sociais, o imperialismo capitalista, a globalização da economia, a revolução científico-tecnológica e o despertar da consciência ecológico-ambiental, promoveram o fortalecimento das correntes de pensamento contrárias ao positivismo, o que se refletiu diretamente nas Ciências Humanas (MENDONÇA, 1993), provocando revisões no modelo de paradigma vigente. Nesse período, a eminência de catástrofes passou a assediar a vida humana no planeta deflagrando um clima de consternação, provocando várias reações de cunho ideológico, destacando-se aquelas de grupos constituídos por ambientalistas.

A citada divulgação de obras e relatórios científicos promoveu a emergência da consciência ambiental, que trazia em seu âmago a certeza de que o modelo de desenvolvimento praticado pelas sociedades humanas não mais condizia com a capacidade de manutenção da vida humana no planeta. Sabe-se que essa "certeza" tem gerado múltiplas dúvidas no meio científico, pois, parafraseando Ilya Prigogine ${ }^{1}$, vive-se atualmente a era do "fim das certezas". Corroboraram para a disseminação dessa idéia as inúmeras conferências que proliferaram no Ocidente, buscando propostas para solucionar ou mitigar os problemas ambientais globais.

Na década de 1980, houve uma revisão dos conceitos de desenvolvimento, até a gênese da expressão desen-

1 Ilya Prigogine (1917) é químico e filósofo belga de origem russa, o qual ganhou o Prêmio Nobel de Química em 1977. Foi ele quem evidenciou a importância dos fenômenos aleatórios e propôs uma teoria dita das estruturas dissipativas. Assim, através de La nouvelle alliance (1979), construiu uma nova metodologia para a investigação científica. 
volvimento sustentável, adotada pela Comissão Mundial sobre Meio Ambiente e Desenvolvimento - CMMAD, surgida a partir do Relatório Brundtland ou Our common future (1987). Estabeleceu-se que desenvolvimento sustentável significaria suprir as necessidades do presente sem comprometer a capacidade das próximas gerações de suprirem as necessidades de seu tempo ${ }^{2}$. Isso se traduzia na necessidade de incorporação nos planos de desenvolvimento, além dos fatores econômicos, as variáveis sociais e ambientais, considerando as consequiências das ações a longo prazo, bem como os resultados em curto prazo. Propondo uma revisão cuidadosa dos processos produtivos, passou-se a objetivar maior produção com menor impacto ambiental questão crucial que acabava se confrontando com a própria lógica de mercado da sociedade capitalista.

Mais do que o equacionamento do conceito de desenvolvimento sustentável, o presente texto busca situar o atual debate nos novos referenciais teóricos e sociais, localizando-os em alguns autores, com ênfase em Enrique Leff $(1994,2000,2001,2002)$ que situa a questão ambiental na problemática de uma crise da civilização, evidenciada pelo fracionamento do conhecimento e pela degradação do ambiente. Essa problemática é marcada pelo logocentrismo da ciência moderna e pelo transbordamento da economização do mundo guiado pela racionalidade tecnológica e pelo livre mercado. O principal objetivo deste trabalho situa-se na discussão do rebatimento das reflexões de Leff na área específica do Pantanal Matogrossense, ${ }^{3}$ em especial no que se refere à incorporação dos estudos sobre o vernáculo na questão do diálogo de saberes. Leff elege como suas categorias centrais de análise a racionalidade ambiental e o saber ambiental, tendo como meta aquilo que se intitula diálogo dos saberes, considerando este primordial para o processo de construção de um novo paradigma que possa estabelecer novas relações entre sociedade e natureza.

De forma complementar visa-se destacar a problemática da interdisciplinaridade e da sustentabilidade socioambiental (FLORIANI, 1998, 2000, 2001; LEFF, 2000a), no panorama contemporâneo do Pantanal, que aponta para o desenvolvimento da arquitetura ecológica ou eco-arquitetura, isto é, para a incorporação de preocupações ambientais na prática profissional a partir de referenciais vernaculares. Busca-se complementaridade entre os pensamentos de Enrique Leff e de Edgar Morin ${ }^{4}$, visto que o primeiro, na produção do conhecimento, também rejeita os princípios da hierarquia, da dedução mecânica e formal e da simplificação. Nesse processo, ambos rejeitam o descarte da idéia de sujeito - a filosofia da consciência, a fenomenologia e a intersubjetividade.

\section{Considerações sobre a racionalidade instrumental}

O desenvolvimento da ciência em sua origem revela a busca por uma racionalidade, a qual se constituiria na desmistificação mitológica e religiosa do mundo. A razão torna-se o mito unificador do saber, da ética e da política. A sociedade também se torna adepta dessa razão, de sua ordem e de sua harmonia. $\mathrm{O}$ racionalismo desenvolve assim uma identidade com o real, com o calculável e com a ordem. E a economia burguesa utiliza-se dessa "razão" como princípio de vida; princípio de economia.

...A ciência progrediu na dupla tensão entre o empirismo e o racionalismo, em que o primado dado à experiência desfaz teorias racionalistas, mas a cada nova desra-

2 Muitos autores contestam veementemente a expressão desenvolvimento sustentável, como, por exemplo, Rodrigues (2000) que expõe a contradição dos termos desenvolvimento e sustentabilidade. Para esta autora, desenvolver é uma meta que implica a produção contínua de mercadorias, necessitando, portanto, de recursos naturais e de lugares para servirem de depósitos dos resíduos; destruindo ou transformando a natureza duplamente. Enquanto que a sustentabilidade significaria a manutenção das condições, ou seja, uma situação impossível em um sistema de produção contínua de mercadorias. Gonçalves (2001), por sua vez, considera o "desenvolvimento sustentável" uma idéia diluidora por ter sido produzida no campo diplomático, portanto, consensual. Este autor ressalta ainda que, por sua natureza, o "desenvolvimento sustentável" apresenta caráter normativo, não científico e, desta forma, deve ser tratado como tal.

3 O Pantanal Mato-grossense é uma área alagável presente nos Estados de Mato Grosso e Mato Grosso do Sul, possuindo cerca de 138.183 km² em território brasileiro e estendendo-se além das fronteiras com a Bolívia e o Paraguai. É definido como "a maior planície de inundação contínua do planeta", segundo a Comissão Interministerial para Preparação da Conferência das Nações Unidas sobre Meio Ambiente e Desenvolvimento - CIMA. Disponível em: <http://www.riosvivos.org.br/ pantanal/>

4 Edgar Morin (1921) é sociólogo francês, inicialmente um observador crítico dos meios de comunicação de massa que, mais tarde, passou a buscar uma compreensão do "indivíduo sociológico" através do que denomina uma aproximação multidimensional, utilizando os recursos da sociologia empírica e da observação compreensiva da realidade cotidiana. Entre suas obras de destaque estão: O Espírito do Tempo (1962), O Paradigma Perdido: a natureza humana (1973), e, o já clássico, O Método, que compreende cinco volumes. 
CASTELNOU, A. M. N. et al. Sustentabilidade socioambiental e diálogo de...

cionalização sucede um esforço novo de inteligibilidade, que provoca uma nova tentativa de re-racionalização. (MORIN, 2001, p. 158)

A ciência desenvolve-se então como verdade, porque através de seus métodos e teorias explica-se o mundo, desfazem-se os mitos, as crenças e as idéias filosóficas. Sua aparência indubitável, baseada em verificações, observações e experimentações, confirmaria sempre os mesmos dados. Sua coerência parecia explicar a coerência do universo. Constituía-se assim uma teoria científica. Mas o surgimento de dados novos pode colocar em "xeque" essa teoria, refutá-la ou torná-la obsoleta e assim há necessidade de uma teoria mais ampla e abrangente. Mudam-se também as "visões" de uma determinada teoria, numa constante busca de aperfeiçoamento dos experimentos e instrumentos. Karl Popper citado por Morin (2001) concebe a ciência como uma construção análoga à seleção natural; segundo ele, a ciência progredia por eliminação de erros na busca da verdade. Enfim, o progresso da ciência dá-se por determinadas regras, por embates de teorias, extremamente objetiva que negocia com o mundo, e se valida, de maneira incontestável, por observações e experimentações que se propõem a comprovar verdades e corrigir erros. Morin propõe: "Se, com efeito, a ciência estabelece um comércio particular com a realidade do mundo dos fenômenos, sua verdade, enquanto ciência, não reside em suas teorias, mas nas regras do jogo da verdade e do erro" (MORIN, 2001, p. 150).

Em conseqüência, o princípio da economia e eficácia adota o desenvolvimento da técnica e a visão racionalista do mundo como base para seu domínio. Aquilo que não se adequa à visão desenvolvimentista, reducionista, é banido. Tudo é explicado em função de interesses econômicos. Tudo o que não participa da economia de mercado e não consome é considerado pobre. A percepção da subsistência como pobreza legitimou o processo de "desenvolvimento" interpretado como um modelo ocidental imposto para a gestão das sociedades pós-coloniais. E a história desse desenvolvimento constitui um capítulo da mesma história que prepara as bases da globalização em curso (FLORIANI, 2003, p. 49).

A ciência, com seu determinismo, torna-se parceira e justificativa do modelo econômico vigente. Através de seus instrumentos e teorias, legitima os processos de padronização que visam o aumento da produção e do capital. No entanto, esse modelo atinge seu limite. E a crise ambiental, representada pela escassez de recursos naturais (matériasprimas), apresenta a necessidade de repensar a natureza não apenas como objeto de apropriação ou como mera externalidade produtiva. As mudanças ambientais globais vieram revolucionar os métodos de investigação e as teorias científicas para apreender uma realidade em vias da complexização que está além da capacidade de compreensão e explicação dos paradigmas teóricos estabelecidos. O discurso científico entra em colapso (LEFF, 1994). A ciência consegue provar seus erros, mas não a verdade da teoria científica. Nenhuma teoria é única sobre a verdade. Nenhuma teoria possui uma única coerência para a explicação do universo.

O processo de globalização com seus crescentes fluxos econômicos, comerciais, tecnológicos e de pessoas tem eliminado barreiras temporais e espaciais, acelerando inclusive as trocas genéticas e culturais. Isso tem sido determinado pelo domínio da racionalidade econômica sobre os demais processos universais. O conceito de desenvolvimento econômico sobrepõe e induz a uma homogeneização e padronização de processos de produção, com vistas à eficácia e ao consumo, reafirmando o sentido unidimensional do mundo e da vida pelo aumento e ganho da produção. Isso se dá antagonicamente à sustentabilidade dos processos planetários, à diversidade ecológica e cultural. A apropriação da natureza como matéria-prima, sua coisificação, e a desnaturalização de sua complexidade ecológica, torna-a simplesmente objeto de exploração do capital. Hoje a natureza deixa de ser esse objeto de trabalho para se tornar, dentro da nova economia ecologizada (LEFF et al., 2002), capital natural, ampliando e generalizando os modos de valorização econômica dessa natureza. Esta transmutação se dá: “(...) junto con las formas ancestrales de explotación intensiva que caracterizaron al 'pillaje del Tercer Mundo' (JALÉE, 1968 op cit.), hoy se promueve una explotación 'conservacionista' de la naturaleza" (LEFF et al., 2002, p. 480).

O conhecimento científico fragmentado não dá conta da questão ambiental colocada e apropriada pelo discurso econômico desenvolvimentista. A problemática ambiental colocou a necessidade de se buscar um conhecimento capaz de captar as multicausalidades e as relações de interdependência dos processos de ordem natural e social que condicionam e delineiam os caminhos socioambientais. Surge então um pensamento da complexidade e uma metodologia interdisciplinar, como uma epistemologia capaz de fundamentar as transformações do conhecimento 
que ressignifica a questão ambiental. Essa estratégia epistemológica parte de um enfoque orientado para a construção de uma raciona-lidade social aberta à diversidade, às interdependências e à complexidade, e oposta à racionalidade dominante tendente à unidade da ciência e à homogeneidade da realidade (LEFF, 1994).

A interface do social com o natural deve priorizar a análise do conflito social e do terreno estratégico das políticas que perpassam o campo ambiental, e não se limitar à internalização de normas ecológicas e tecno-lógicas pelas teorias e políticas econômicas. As formações teóricas e ideológicas de uma nova proposta de conhecimento, assim como as práticas do ambientalismo, propõem a reorientação de valores, a instrumentação de normas e o estabelecimento de políticas para a construção dessa nova racionalidade social. A transformação crítica dos processos, das instituições, dos aparelhos ideológicos que sustentam a racionalidade econômica dominante, constitui-se em base para a construção de uma racionalidade social, baseada em outros princípios de gestão ambiental e de desenvolvimento sustentável.

Ao definir a racionalidade como o estabelecimento de adequação entre uma coerência lógica e uma realidade empírica, Morin destaca que em fins do século XVIII a razão torna-se, para a ciência ocidental, o grande mito unificador do saber, da ética e da política, ressaltando que: “...como no princípio de razão há o princípio de economia, a vida segundo a razão é conforme aos princípios utilitários da economia burguesa" (Morin, 2001, p. 159). O desenvolvimento econômico-tecnoburocrático das sociedades ocidentais produziu uma racionalização instrumental, em que "eficácia e rendimento parecem trazer a realização da racionalidade social", dando destaque à "sociedade industrial" como sinônimo de racionalidade em relação às outras sociedades, consideradas infra-racionais (MoRIN, 2001).

Para Morin (2001), a industrialização, a urbanização, a burocratização e a tecnologização se efetuaram segundo as regras da racionalização, da manipulação dos indivíduos visando aos princípios de ordem, de economia, de eficácia, constituindo-se num processo de manipulação generalizada, para agir não só sobre a natureza, mas também sobre a sociedade:

...assim, nessa lógica, produz-se não só uma burocracia para a sociedade, mas também uma sociedade para essa burocracia; não só se produz uma tecnocracia para o povo, mas também se constrói um povo para essa tecnocracia; não só se produz um objeto para o sujeito, mas também, segundo a frase de Marx à qual hoje se podem dar prolongamentos novos e múltiplos, "se produz um sujeito para o objeto”. (MORIN, 2001, p. 164)

\section{A questão da complexidade ambiental}

Após as décadas de 1970 e 1980, os problemas ambientais passaram a ser reconhecidos como sistemas complexos, nos quais interviriam processos de diferentes racionalidades, ordens de materialidade e escalas espaçotemporais. Essa problemática relacionada ao meio ambiente, de acordo com a UNESCO (1986), consistiria no campo privilegiado das inter-relações sociedade-natureza, razão pela qual seu conhecimento demanda uma abordagem holística e um método interdisciplinar, os quais permitiriam a integração das ciências da natureza e da sociedade; das esferas do ideal e do material; da economia, da tecnologia e da cultura. Assim, desde então, uma reflexão epistemológica e metodológica sobre complexidade e interdisciplinaridade ambiental faz-se presente no debate contemporâneo.

Em termos gerais, pode-se dizer que se evoluiu de uma visão naturalista e ecologista, a qual considerava essencialmente os aspectos biológicos e físicos, expressa por pesquisadores como Morin (1973) no início, e Wilson (1975) desde sempre, para uma concepção mais ampla, voltada às questões econômicas, sociais e culturais; percebe-se que, se os primeiros aspectos (físico-biológicos) constituem a base natural do ambiente humano, as segundas questões (socioculturais) definem as orientações conceituais, os instrumentos técnicos e os comportamentos práticos de que os homens se utilizam para satisfazer suas necessidades, o que incluiria também a arquitetura, dentre outros. Segundo Leff (2000a), da concepção de uma educação ambiental fundada na articulação interdisciplinar das ciências naturais e sociais, avançou-se atualmente para uma visão da complexidade ambiental aberta às diversas interpretações do ambiente e a um consistente diálogo de saberes.

Assim, as estratégias alternativas de conhecimento implicam em um processo de inter-relação de procedimentos cognitivos que transbordariam e transcenderiam o campo 
específico da pesquisa e do ensino, das disciplinas científicas e de suas articulações possíveis. Na atualidade, devido à complexidade da questão ambiental, torna-se fundamental a conjugação de diversas visões, habilidades, conhecimentos e saberes dentro de práticas de educação, de análise e de gestão ambiental, as quais implicariam em diversas "disciplinas" - entendidas como formas e modalidades de trabalho - mas que não se esgotariam apenas em uma simples relação entre disciplinas científicas (LEFF, 2000a). Na realidade, somente com a emergência de uma nova racionalidade - desta vez, a ambiental - é que se poderia compreender profundamente a relação sociedade-natureza na contempora-neidade.

Ainda de acordo com Leff (2000a), na sociedade "supercientifizada" e "hipertecnologizada" contemporânea, tanto os que dominam, quanto os subjugados, mantêm-se alienados de seus mundos de vida, em um mundo no qual a incerteza, o risco e o descontrole aumentam proporcionalmente o perigo dos efeitos do domínio da ciência sobre a natureza. Numa referência à Risk Society de Ulrich Beck (1992), isso é agravado pelo próprio pragmatismo político, que busca resolver as urgências da crise socioeconômica e ecológica pela via da eficácia dos processos científicos e tecnológicos. Karl Marx (1818-1883) e o projeto revolucionário socialista desmascaravam a ideologia burguesa, assim como o socialismo utópico, que procurou construir um socialismo científico fundado em um materialismo dialético, não chegaram porém a questionar as formas históricas do conhecimento como raiz e causa de exploração da natureza e da submissão das culturas.

Desse modo, o conhecimento científico continuou sendo a alavanca do progresso econômico. Somente Friedrich Nietzsche (1844-1900), Martin Heidegger (18891976) e, mais tarde, os filósofos de Frankfurt, traçariam o perfil de uma crítica radical das raízes do pensamento metafísico, da ciência positivista e da racionalidade tecnológica em sua vontade de universalidade, homogeneidade e unidade do conhecimento, de objetivação e coisificação do ser, o que gerou a atual globalização unidimensional, regida e valorizada pelo modelo econômico (LEFF, 2000a). A partir da interrogação sobre as formas pelas quais o conhecimento e a teoria reconstroem a realidade, tornou-se possível uma reflexão crítica sobre os fundamentos e os sentidos do conhecimento; também sobre suas fissuras e fracionamentos, assim como sobre a possibilidade de reintegrar conhecimentos e saberes que, além de retotalizarem visões holísticas e métodos sistêmicos, possibilitem uma reapropriação do mundo pela via do saber. É nessa perspectiva que hoje se inscreve a reflexão sobre a prática interdisciplinar fundada em uma racionalidade ambiental.

A necessidade de uma estratégia epistemológica para a interdisciplinaridade ambiental é apontada por Leff (2000a) de modo a combater as ideologias teóricas geradas pela ecologia generalizada e pelo pragmatismo funcionalista, rompendo respectivamente com os efeitos ideológicos do reducionismo ecologista e do funcionalismo sistêmico, que pensam o homem e as formações sociais como populações biológicas inseridas no processo evolutivo dos ecossistemas - explicando a conduta humana e a práxis social através de determinações genéticas ou de sua adaptação funcional ao meio - e acreditam ser a ecologia a disciplina mais importante da relação homem-natureza, elegendo-a a "ciência das ciências"; ou ainda fundando a interdisciplinaridade na Teoria Geral dos Sistemas, de Bertalanffy (1976).

Conforme Prigogine (1996), já não cabe à ciência e aos cientistas de hoje reafirmarem verdades, pois o próprio mundo - ou o ser humano - se descobriu como visceralmente incerto. Desde que se descortinem novas possibilidades para pensar outras possibilidades de pensar, os aparelhos lógico-metodológicos dos sistemas científicos tornamse frágeis, ao incorporarem reflexivamente um alto grau de incerteza: o que era certeza para os saberes organizados torna-se hoje incerteza organizada. Mesmo as ciências mais consagradas, como a física e a biologia, abrem-se atualmente para outras ciências e internalizam o risco da dúvida metódica. A noção de verdade na ciência, é uma invenção humana. Embora criativa é falível, a exemplo de sua aplicação em outras esferas da atividade humana (religião, moral, etc.) (FLORIANI, 2000).

Assim, no âmbito da problemática ambiental, os fundamentos teóricos sobre uma nova forma de produção do conhecimento não podem ser dissociados da prática interdisciplinar, esta entendida como a articulação de diversas disciplinas para melhor compreender e gerir situações de acomodação, tensão ou conflito explícito entre as necessidades e as práticas humanas e as dinâmicas naturais. A noção de meio ambiente deve ser multicêntrica, complexa e composta por objetos de diferentes escalas de abordagem. Paralelamente, a dimensão ambiental não pode deixar de ser reconhecida como um dos eixos centrais dos processos de desenvolvimento. Segundo Raynaut (1996), as complexas e diversificadas temáticas do meio ambiente e 
do desenvolvimento exigem, mais do que causalidades lineares e níveis de apreensão disciplinares, um enfoque que leve em conta centralmente as análises das interações entre as sociedades humanas e a natureza.

Além disso, de acordo com Floriani (1998), a construção de conhecimentos interdisciplinares deve evitar certas tentações ingênuas, como aquelas que buscam "linguagens comuns" entre as disciplinas; ou ainda a formação de "generalistas" em meio ambiente, presumivelmente dotados de competência universal, auto-suficientes e retoricamente desvinculados do conhecimento disciplinar. A interdisciplinaridade necessita de uma intenção deliberada, assentada em trocas intersubjetivas sistemáticas, a partir do confronto de saberes disciplinares e que leve em conta uma ou mais problemáticas na relação sociedade-natureza. Pode-se definir, genericamente, a experiência interdisciplinar como o diálogo de diversos saberes organizados ou disciplinares que, no âmbito do meio ambiente e desenvolvimento, desenham estratégias de pesquisa, diferentemente do que faria cada disciplina, por seu lado, fora dessa interação. Há assim uma hibridação de saberes que se abre para aqueles reconhecidos cientificamente e, também, aos saberes chamados tradicionais e/ou alternativos, não tão valorizados pela racionalidade instrumental hegemônica.

Para Leff et al. (2002), a proposta de desenvolvimento sustentável deve ir além da idéia de uma articulação das ciências para alcançar uma gestão ambiental do desenvolvimento, para estabelecer uma re-articulação ou hibridação de conhecimentos científicos e saberes tradicionais.

Morin condiciona o desenvolvimento da ciência a um processo instável de desracionalizações e re-racionalizações. Recorrendo a Kuhn, o autor afirma: "a história das ciências aparece não como um progresso contínuo e cumulativo, mas como uma série de revoluções desracionalizantes, provocando, cada uma, nova racionalização" (MORIN, 2001, p. 166). Diante da dinâmica constante do processo evolutivo da razão e da complexidade da sociedade contemporânea, Morin propõe uma nova razão, a razão crítica, uma razão aberta que possa dar conta de perceber e "reconhecer que há fenômenos simultaneamente irracionais, racionais, a-racionais, sobrer-racionais, como talvez, o amor..." (MORIN, 2001, p. 168). Uma razão autocrítica e evolutiva que reconheça os limites da lógica. Este autor, nesta obra, enfatiza que o real excede sempre o racional, para tanto a razão deve se desenvolver e tornar-se complexa.
Morin (2001) propõe ainda um diálogo recorrente entre a sociedade e a natureza e, para tanto, a ciência deveria se despojar de todos os dogmas engendrados em sua evolução histórica. Para este autor, a ciência moderna ocidental sempre se revestiu de um caráter de complexidade, "mesmo quando tinha por objetivo único revelar as leis simples que governam o universo e a matéria de que ele é constituído" (MORIN, 2001, p. 8). Nessa fase, a ciência "só vivia em e por uma dialógica de complementaridade e de antagonismo entre empirismo e racionalismo, imaginação e verificação". O autor também reafirma a complexidade da ciência em função de sua inseparabilidade com seu contexto histórico e social, revelada, por exemplo, pela sua emergência "na efervescência cultural da Renascença, na efervescência econômica, política e social do Ocidente europeu dos séculos XVI e XVII" (MORIN, 2001, p. 9).

Para desvendar essa complexidade latente, Morin propõe também o diálogo recorrente em que as diversas disciplinas possam coordenar em torno de uma concepção organizadora comum. Contudo, a proposta de Morin resvala na possibilidade de se buscar uma disciplina globalizante, como a ecologia, por exemplo, a fim de se "entrefecundar numa questão ao mesmo tempo crucial e global, como a questão cosmológica, em que as diversas ciências físicas, utilizadas pela astronomia, concorrem para conceber a origem e a natureza de nosso universo" (MORIN, 2001, p. 9).

Embora controversa, a questão de uma "refundação" do conhecimento, via aglutinação, fusão ou associação, encontra em Morin uma proposta para uma reforma do pensamento, através da complexidade, e esta só poderá viabilizar-se diante de uma nova proposição epistemológica, incluindo aí rupturas dos paradigmas da ciência moderna. As ciências, humanas e/ou naturais, através do diálogo recorrente, deverão produzir traduções das realidades do mundo exterior. A teoria, por sua vez, não deve ser vista como o conhecimento, embora permita o conhecimento. Para Morin, citado por Floriani, a teoria não deve ser como uma receita, nem um fim em si mesma; deve ser sempre um meio para se atingir a um fim: o conhecimento (FLORIANI, 2003). Assim, a teoria deve ser recriada permanentemente e a cientificidade deve traduzir o real em teorias mutáveis e renováveis. Por fim, a ciência deve transgredir criativamente as fronteiras do conhecimento para atingir a chamada transdisciplinaridade. 
CASTELNOU, A. M. N. et al. Sustentabilidade socioambiental e diálogo de...

\section{A construção da racionalidade ambiental}

Ao analisar o conceito de racionalidade no pensamento weberiano, Leff (1994) define a racionalidade social como o sistema de regras, de pensamento e comportamento dos atores sociais que se estabelecem dentro de estruturas econômicas, políticas e ideológicas determinadas, legitimando um conjunto de ações e conferindo um sentido à organização da sociedade em seu conjunto. Por sua vez, essas regras orientam um conjunto de práticas e processos sociais visando certos fins, através de meios socialmente construídos, refletindo-se em suas normas morais, em suas crenças, em seus arranjos institucionais e em seus padrões de produção.

Weber, segundo Leff (1994), define os seguintes tipos de racionalidade: teórico-formal, instrumental e substantiva. Estes operam sobre as esferas institucionais da economia, direito e religião. Esse conceito abre importantes perspectivas à análise da problemática ambiental, pela referência direta às relações entre os processos sociais e naturais, mas ainda também permite integrar os diferentes processos sociais que dão coerência e eficácia aos valores materiais e aos valores culturais que organizam uma formação social ambientalmente sustentável. Articulam processos discursivos, ideológicos, teóricos, técnicos e institucionais, que orientam e legitimam o comportamento social frente à natureza, projetando ações para a construção de uma racionalidade ambiental e pondo em prática os processos de gestão participativa da sociedade sobre recursos produtivos, orientados para os objetivos de um desenvolvimento sustentável. Uma releitura de Weber, para o autor que o refere, possibilita a incorporação de uma multiplicidade de forças e ações sociais de mudança de racionalidade social para analisar a transição até uma sociedade construída sobre os valores do ambientalismo. Apreendendo os sistemas sociais dentro de seus traços singulares abre-se a análise da diversidade cultural, que caracteriza a racionalidade ambiental, aos sentidos subjetivos que definem a qualidade de vida e as motivações dos atores sociais do ambientalismo.

Esse conceito complexo permite analisar a coerência de um conjunto de processos sociais, aplicável à construção de uma teoria da produção e da organização social com base na gestão ambiental, no desenvolvimento sustentável, no eco-desenvolvimento. Com base nesta análise, Leff (1994) propõe a sistematização dos princípios materiais e axiológicos do discurso ambientalista, organizando os argumentos do saber ambiental, e analisando a consistência e eficácia de um conjunto de ações que sustentam os objetivos desse discurso, por meio do conceito de racionalidade ambiental.

$\mathrm{Na}$ concepção de Leff (2000b), esta racionalidade ambiental deve incorporar os princípios que sustentam uma teoria alternativa que incorpora os valores da natureza e da democracia participativa em novos esquemas de participação social. Esses valores e direitos estão sendo legitimados e normatizados no comportamento social, mobilizando processos materiais e ações sociais gerando assim padrões alternativos de produção, novos estilos de consumo e vida. Urge a implementação de instrumentos eficazes de políticas públicas para legitimar estes princípios e valores; de instrumentos de avaliação e execução dessa nova racionalidade ambiental, e de meios que assegurem a eficácia das estratégias políticas, das transformações produtivas e de suas ações sociais.

Com otimismo, podemos vislumbrar na questão ambiental novas perspectivas para o desenvolvimento, descobrindo novos potenciais ecológicos, tecnológicos e sociais e propondo a transformação dos sistemas de produção, de valores e de conhecimento da sociedade, como diz Leff (1994:35), em uma "racionalidade produtiva alternativa". Nesse sentido, esta racionalidade produtiva alternativa, também intitulada por este autor como racionalidade ambiental, emerge de uma crítica da economia política do ambiente, tendo por objetivo a transformação da racionalidade produtiva vigente, ou seja, o rompimento com a

...concepção reducionista do homem na sua função de
trabalho e com a racionalidade econômica dominante,
para trazer as potencialidades da Natureza e da Cultura
para os processos produtivos. Esta racionalidade pro-
dutiva situa-se, assim, no processo ideológico que
universalizou a dimensão do trabalho, das necessidades
e da produção, abrindo possibilidades para a constru-
ção de novos "modos de produção". (LEFF, 2000b, p. 150)

Entretanto, nesta mesma obra Leff destaca que o conceito de racionalidade ambiental possui um sentido mais amplo quando se refere aos valores da democracia, às relações de poder e ao sentido da existência humana. Para o autor, através do conceito de qualidade de vida, o ambientalismo aponta para a emancipação da racionalidade eco- 
nômica e da racionalidade teórica. A formação de uma consciência ambiental ou ecológica, a transformação democrática do Estado permitindo a participação da sociedade e das comunidades na autogestão e co-gestão de seu patrimônio de recursos, a reorganização transetorial da administração pública, a reelaboração interdisciplinar do saber levará a construção dessa nova racionalidade produtiva.

Ao conceito de racionalidade ambiental insere-se um conceito de "adaptação" que predomina sobre o conceito de "domínio" da natureza em que se apóia a racionalidade capitalista e os paradigmas da ciência moderna (LEFF,1994). Essa racionalidade não se reduz a um padrão único de medida, nem às preferências de um mercado consumidor, visto que os processos ecológicos, os valores humanos e direitos ambientais não se valoram de forma monetária. Neste sentido, a racionalidade ambiental constitui-se numa crítica à racionalidade da civilização moderna. Ela propõe a desconstrução da racionalidade econômica, baseada nas forças do mercado e produção infindável, para a construção de outra racionalidade fundada em outros valores e princípios, outras forças materiais, e meios técnicos, através da mobilização de recursos humanos, culturais e gnosiológicos.

Dentro do discurso apresentado por Leff, a construção dessa racionalidade ambiental, alternativa, mas produtiva, pressupõe a articulação de quatro níveis de raciona-lidade:

1) a racionalidade substantiva que trata de um sistema axiológico baseado em princípios de um desenvolvimento ecologicamente sustentável, socialmente eqüitativo, culturalmente diverso e politicamente democrático;

2) a racionalidade teórica que constrói conceitos que articulam os valores da racionalidade substantiva com os processos materiais que dão suporte a uma racionalidade produtiva fundada em uma produtividade ecotecnológica e um potencial ambiental de desenvolvimento;

3) a racionalidade instrumental que produz, através de um sistema tecnológico adequado, de procedimentos jurídicos para a defesa dos direitos ambientais e meios ideológicos e políticos, vínculos funcionais e operacionais entre os objetivos sociais e as bases materiais do desenvolvimento sustentável;

4) a racionalidade cultural que consiste em um sistema de significações que produz identidade e integridade a diversas formações culturais, que dá coerência a suas práticas sociais e produtivas; e estabelece a singularidade de racionalidades ambientais heterogêneas que cobrem sentido e realidade em nível de ações locais e não se submetam a uma lógica ambiental geral. (LEFF, 2001b, p. 137)

Ao confrontar a racionalidade ambiental com a racionalidade econômica, Leff (2001b) discorre sobre os pontos que legitimam esse conceito e que necessitam ser mais bem trabalhados e elaborados. O autor coloca a construção da racionalidade ambiental como um conjunto de racionalizações, com diferentes instâncias de racionalidade que conferem legitimidade à tomada de decisões com respeito à transformação da natureza e no uso dos recursos, dando funcionalidade às suas operações práticas e eficácia aos seus processos produtivos. Esse processo de construção implica em processos políticos e sociais que superem a confrontação das lógicas opostas. Um processo transformador de formações ideológicas, instituições políticas, funções governamentais, normas jurídicas, valores culturais, estruturas tecnológicas e comportamentos sociais. A racionalidade ambiental se apóia mais na legitimação de seus valores (pluralidade étnica, fortalecimento de economias auto-gestionárias não-acumulativas), do que em seus meios instrumentais. $\mathrm{O}$ conceito de qualidade de vida $\mathrm{e}$ qualidade ambiental como objetivo da estratégia ambiental de desenvolvimento funda sua racionalidade nos valores qualitativos de seus objetivos, em uma racionalidade substantiva, entendida como um sistema de significações, valores e normas culturais caracterizadas por sua diversidade e relatividade.

Essa dialética social deve induzir à transformação do conhecimento e das bases materiais dos processos produtivos:

O conflito teórico, social e político, sobre natureza-sociedade, faz emergir uma nova racionalidade ambiental, como "efeito de conhecimento". Dessa maneira, a racionalidade ambiental depende de um saber ambiental que ultrapassa tanto a racionalidade como a objetividade do conhecimento científico. Por isso que o saber ambiental procura o que as ciências ignoram (FLORIANI, 2003, p. 2).

A epistemologia ambiental emerge do encontro da epistemologia materialista e do pensamento crítico com a 
CASTELNOU, A. M. N. et al. Sustentabilidade socioambiental e diálogo de...

questão ambiental. Leff considera-a mais do que um projeto com a finalidade de apreender um conhecimento, mas

\begin{abstract}
...um trajeto para chegar a saber o que é o ambiente, esse estranho objeto do desejo de saber que emerge do campo de externalidade e de extermínio para o qual foi enviado, expulso do logocentrismo e do círculo de racionalidade das ciências. $\mathrm{O}$ ambiente não é ecologia, mas a complexidade do mundo; é um saber sobre as formas de apropriação do mundo e da natureza através das relações de poder que se inscreveram nas formas dominantes de conhecimento. A partir daí, abre-se o caminho que seguimos para delinear, compreender, internalizar e finalmente dar seu lugar - seu nome próprio - à complexidade ambiental. (LEFF, 2001a, p. 17)
\end{abstract}

\section{Do diálogo de saberes ao saber ambiental}

No intuito de propor uma reforma do conhecimento para captar a dimensão ambiental, Leff (2001a) dá ênfase à necessidade de estabelecimento de conexões com as demais formas de saber, pois, para ele, o ambiente encontrase integrado por processos, de ordem física e social. $\mathrm{O}$ autor apresenta o ambiente como uma categoria sociológica, relativa a uma racionalidade social, configurada por comportamentos, valores e saberes, bem como por novos potenciais produtivos.

A construção do novo saber implica na integração interdisciplinar do conhecimento que explique o comportamento de sistemas socioambientais complexos. O saber ambiental não se esgota nos paradigmas da ecologia, nem se limita a um componente ecológico dos paradigmas atuais do conhecimento. Ele excede as "ciências ambientais", constituídas por um conjunto de especializações que incorporaram enfoques ecológicos às disciplinas tradicionais. Para Leff (2001a), o saber ambiental é um saber sobre o campo externalizado pela racionalidade econômica, científica e tecnológica da modernidade, mas que também conota os saberes marginalizados e subjugados pela centralidade do logos científico. A questão ambiental gera um processo de fertilizações transdisciplinares por meio da transposição de conceitos e métodos entre diferentes campos do conhecimento. "Nesse processo vai se definindo o 'ambiental' de cada ciência centrada em seu objeto de conhecimento, que leva a sua transformação para internalizar o sa- ber ambiental que emerge em seu entorno" (LEFF, 2001a, p. 163).

O saber ambiental se gesta por meio da transformação de um conjunto de paradigmas do conhecimento e de formações ideológicas, a partir de uma problemática social que os questiona e os ultrapassa. Leff (2001a) descreve de maneira entusiasmada a emergência do saber ambiental: como um saber que se estende além do campo de articulação das ciências, abre-se ao terreno dos valores éticos, dos conhecimentos práticos e dos saberes tradicionais. O saber ambiental surge do espaço de exclusão das ciências, que produz desconhecimento de processos complexos não explicáveis pelas disciplinas. Do campo das externalidades da economia, que não sabe o que fazer dos processos naturais e culturais, dentro de sua lógica de mercado, que gera as diferenças de renda e a desigualdade social, pela maximização de benefícios em curto prazo. A partir de sua marginalidade o saber ambiental expressa as verdades silenciadas, os saberes subjugados e submetidos ao poder objetivista e determinista do pensamento científico. O estruturalismo crítico desse novo saber, o pensamento da complexidade e do discurso ambiental provocam uma crítica da razão analítica e da autoconsciência do sujeito como princípios do conhecimento objetivo e da unificação do saber.

A partir do pensamento da complexidade, os princípios de racionalidade ambiental comprometem-se com - e informam - uma multiplicidade de experiências e práticas que se firmam no singular de cada cultura e configuram uma especificidade local, partindo de uma diversidade que estrutura uma nova racionalidade. O saber ambiental anseia pela busca de novos sentidos de civilização, novas compreensões teóricas e novas práticas de apropriação do mundo. Esse saber se constrói a partir da falta de conhecimento, integrando princípios e valores que animam a ética ecologista, as sabedorias e práticas tradicionais de manejo dos recursos naturais e as ciências técnicas que servem de suporte às estratégias de desenvolvimento sustentável. Vai se construindo em relação com a estrutura teórica e o objeto de conhecimento de cada ciência. Na consciência ambiental são gerados novos princípios, valores e conceitos para essa nova racionalidade produtiva e social, projetos alternativos de vida e desenvolvimento. O saber ambiental é então gerado num processo de conscientização, de produção teórica e de pesquisa científica.

O problema da articulação da temporalidade e da espacialidade de diferentes processos naturais e sociais, tem lugar no saber ambiental, assim como a harmonização ou 
conflito entre os ciclos econômicos e ecológicos; entre a valorização econômica e os valores culturais; entre a maximização dos ganhos e o tempo de regeneração dos recursos naturais e os processos de inovação tecnológica e sua assimilação; entre espaços ecológicos, geográficos, culturais, políticos, sociais, econômicos onde se concretizam as ações de gestão ambiental.

Faz-se necessário, para aplicação desse saber aos programas de gestão ambiental, a elaboração de instrumentos, capazes de analisar, avaliar e monitorar esses sistemas complexos, que se compõem de processos de diversos níveis de materialidade e ordens de racionalidade (LEFF, 2001b).

Uma transformação geral dos paradigmas estabelecidos do conhecimento para assim internalizar um saber ambiental, que, segundo Leff (2001a), é muito mais que uma visão holística e uma vontade sistêmica: é um diálogo de saberes, o qual acarretaria em uma abertura à inter-relação, ao confronto e ao intercâmbio de interesses, numa relação diametral que vai da solidariedade e complementaridade entre disciplinas, ao antagonismo de saberes, no qual se inter-relacionam mais processos significativos que posições científicas, interesses disciplinares e verdades objetivas.

O propósito de unificação das ciências no positivismo lógico e a busca de suas homologias estruturais na Teoria Geral dos Sistemas desconheciam a especificidade conceitual de cada ciência de onde seria possível pensar sua integração com outros campos do conhecimento, sua articulação com outros processos materiais e sua hibridação com outros saberes (LEFF, 2001a).

O diálogo de saberes, proposto por Leff (2001a), para o qual convoca a complexidade ambiental, trata do encontro de tradições e formas de conhecimento legitimadas por diferentes matrizes de racionalidade, por saberes arraigados em identidades próprias que não só entram em jogo num processo de tomada de decisões, mas que se "hibridam" na co-determinação de processos materiais. A construção do saber ambiental leva ao diálogo uma diversidade de saberes de diferentes e altos níveis de abstração conceitual até os saberes práticos e cotidianos em que se expressam as estratégias. A miscigenação desses saberes não conduz a uma unificação, mas leva ao surgimento de novas forças sociais e potenciais ambientais, que fundam uma nova ordem de onde fazem surgir uma nova ética, elaborando uma nova racionalidade construída de novas subjetividades (LEFF, 2001b).

Leff (2001a) ainda afirma que o diálogo de saberes na gestão ambiental implica na participação de pessoas no processo de produção, de suas condições de existência. Seria o encontro entre a vida e o conhecimento, a confluência de identidades e saberes. O saber ambiental se faz intrínseco às comunidades locais integrando a gestão ambiental local, quando se fundem então a consciência de seu meio, o conhecimento de suas propriedades e formas de manejo sustentável de seus recursos, com sua simbologia e o sentido de práticas sociais que integram diversos processos no intercâmbio de saberes sobre o ambiente:

1) o saber ambiental de cada comunidade inserido em suas formações ideológicas, suas práticas culturais, suas técnicas tradicionais;

2) o saber ambiental que é gerado na sistematização e no intercâmbio de experiências de uso e manejo sustentável dos recursos naturais;

3) a transferência e aplicação de conhecimentos científicos e tecnológicos sobre um meio ambiente, sua apropriação cultural e sua assimilação às práticas e saberes tradicionais de uso dos recursos. (LEFF, 2001b, p. 153-4)

Uma "cultura ecológica" tem sido incentivada mobilizando processos sociais para o desenvolvimento sustentável baseado em racionalidades culturais, constituídas de diferentes formas de organização simbólica e produtiva dos povos indígenas e das comunidades camponesas. Um complexo sistema de valores, ideologias, significados, práticas produtivas e estilos de vida se desenvolveram ao longo da história, em diferentes contextos geográficos e ecológicos, atualizando-se, no presente, com estratégias alternativas de sustentabilidade frente à racionalidade imperante do mercado global (LEFF et al. 2002).

De acordo com Leff (2000b), para entender o funcionamento dessas estratégias culturais de manejo sustentável dos recursos naturais, presentes nas tradições dos povos, é preciso compreender a racionalidade cultural que subsiste nas classificações da natureza, refletindo o conhecimento local de diferentes grupos étnicos, expressos por sistemas de crenças, saberes e práticas que formam seus "modelos holísticos" de percepção e uso dos recursos (PITT, 1985). Isto constitui um patrimônio natural e cultural, tanto das populações indígenas como de sociedades rurais em qualquer parte do mundo.

As estratégias alternativas para o desenvolvimento sustentável, baseadas na diversidade cultural, estão legitimando os direitos das comunidades sobre seus territórios e espaços étnicos, sobre seus costumes e instituições sociais 
pela gestão de seus recursos produtivos. Os princípios de diversidade, no ambientalismo, se contrapõem à homogeneidade de padrões produtivos dominantes, e defendem os valores da diversidade de contextos ecológicos, a pluralidade cultural e a preservação das identidades dos povos. Estes princípios éticos aparecem como uma condição para alcançar os objetivos do desenvolvimento sustentável em escala local e global (LEFF et al., 2002).

Muitas das condições ecológicas e culturais de uma sustentabilidade se incorporaram às práticas produtivas das sociedades tradicionais, e se refletem tanto em suas formações simbólicas como em seus instrumentos tecnológicos, configurados em largos processos de co-evolução com a natureza, de transformação ambiental e assimilação cultural (LEVI-STRAUSS, 1972; DESCOLA, 1996; citados por LEFF et al., 2002). As práticas produtivas fundadas na simbolização cultural do ambiente, em crenças religiosas e em significados sociais atribuídos à natureza, geraram diferentes formas de percepção e apropriação, regras sociais de acesso e uso, práticas de gestão de ecossistemas e padrões de produção e consumo de recursos. Desta maneira se configuram as ideologias agrícolas tradicionais e as estratégias produtivas mesoamericanas assim designadas por vários autores (ALCORN, 1989; BOEGE, 1988; MORELLO, 1986; citados por LEFF, 2002).

Leff et al. (2002) observam que as culturas autóctones resistiram e assimilaram processos de aculturação e mudança tecnológicas no curso de suas histórias, reafirmando e transformando seus traços identitários. As populações indígenas têm sido levadas a ressignificar suas identidades e hibridar suas culturas frente às estratégias econômicas e tecnológicas para se reapropriar da natureza e da biodiversidade. Hoje a cultura está sendo revalorizada como um recurso para o desenvolvimento sustentável. E a cultura desses povos aparece como parte integrante do seu patrimônio de recursos naturais, definido por relações simbólicas e produtivas que guiaram a co-evolução da natureza e a cultura através dos tempos.

A cultura aparece como um princípio ativo para o desenvolvimento das forças produtivas, em um paradigma alternativo de sustentabilidade. A produtividade ecológica e a inovação tecnológica estão entremeadas com os processos culturais que definem a produtividade social de cada comunidade, e essas, por sua vez, se enlaçam para gerar uma economia global alternativa, fundada em forças produtivas da natureza e nos sentidos criativos da cultura (LEFF et. al., 2002).
A percepção holística do meio ambiente, ainda segundo Leff (2000b), confere um papel fundamental aos sistemas cognitivos das sociedades tradicionais. Suas cosmovisões integram seus mitos e rituais e suas práticas produtivas; seu conhecimento dos fenômenos geofísicos está associado ao conhecimento dos diferentes tipos de solos e condições topográficas, permitindo o aproveitamento do espaço ecológico e gerando estratégias de uso múltiplo e integrado dos recursos. Estas práticas de uso integrado e múltiplo de recursos naturais estão baseadas em normas culturais e conhecimentos tradicionais que codificam o meio ambiente, preservando a biodiversidade e incrementando a capacidade das comunidades de satisfazer as necessidades materiais e suas aspirações culturais. A natureza se converte em recurso econômico e patrimônio cultural (LEFF et al., 2002).

A partir dessas constatações, esses autores atribuem aos povos criadores e gestores dos saberes tradicionais o papel de novos sujeitos sociais e políticos. Com a incorporação dos valores culturais, o desenvolvimento pleno do diálogo de saberes se dará em um marco do interculturalismo e da diversidade, porém gerando e delineando a luta pelo pluralismo ideológico e religioso, a educação intercultural, a autogestão, a autonomia, e ainda a transição dos estados nacionais até estados pluriculturais com regimes cada vez mais democráticos.

Para Leff et al. (2002) é importante destacar que o espaço e o lugar estão sendo reinventados, a partir das identidades culturais para enraizar e especificar as condições de sustentabilidade, de cujas construções o logocentrismo das ciências havia se extraviado, perdendo seus referenciais geográficos e seus sentidos culturais. A política do lugar está emergindo, mobilizada pelos direitos à identidade e à diferença cultural dos povos, legitimando as regras mais plurais e democráticas.

Esses autores ainda definem o lugar como o território onde a sustentabilidade se encerra em bases ecológicas e identidades culturais; o espaço social onde os atores exercem o poder de controlar a degradação ambiental e mobilizam os potenciais ambientais em projetos autogeridos e gerados para satisfazer suas necessidades e aspirações; o nível local onde se formam as identidades culturais, onde se expressa uma valorização social dos recursos econômicos e como estratégias de reapropriação da natureza. O local é onde emergem as sinergias positivas da racionalidade ambiental. Os territórios culturais estão sendo fertilizados por um tempo pleno de significados. 
Para Leff (2000b), enquanto o discurso do desenvolvimento sustentável está sendo assimilado pela racionalidade econômica e por políticas de capitalização da natureza, os princípios da sustentabilidade estão se enraizando em âmbito local através da construção de novas racionalidades produtivas, sustentada em valores e significados culturais, em potencialidades ecológicas da natureza e na apropriação social da ciência e tecnologia.

Por constituir-se em novas identidades nas quais se inscrevem os atores sociais que mobilizam a transição para uma racionalidade ambiental, o saber ambiental se produz numa relação entre teoria e práxis. O conhecer se abre para novos sentidos civilizatórios, implicando na desconstrução da racionalidade vigente, que engendrou a crise ambiental, para gerar um novo saber no qual se reinscreve o ser no pensar e se reconfiguram as identidades mediante um diálogo de saberes, na dimensão aberta pela complexidade ambiental para o re-conhecimento e a re-apropriação do mundo. (LEFF, 2000b, p. 188-189).

Nessa mesma linha Morin afirma que os progressos gigantescos dos conhecimentos no âmbito das especializações disciplinares, durante o século XX, produziram conhecimento compartimentado, disperso, muitas vezes abstraído do contexto, do global e do complexo. Os problemas fundamentais e os problemas globais estão ausentes das ciências disciplinares assim "as mentes formadas pelas disciplinas perdem suas aptidões naturais para contextualizar os saberes" (Morin, 2000:40). Continua, destacando, que o enfraquecimento da "percepção global conduz ao enfraquecimento da responsabilidade (cada qual tende a ser responsável apenas por sua tarefa especializada), assim como ao enfraquecimento da solidariedade (cada qual não sente os vínculos com seus concidadãos)" (MORIN, 2000, p. 41).

O renascimento das etnias e a revalorização da diversidade cultural geraram uma nova compreensão da relação entre sociedade e natureza; objetivo e subjetivo; real e simbólico. As sociedades tradicionais, os saberes vernáculos e as economias locais passam então a compor, juntamente com a construção de um saber ambiental, uma reconstrução do conhecimento a partir de novas visões, potencialidades e valores, guiados por novas significações e sentidos civilizatórios. Enfim, a história contemporânea abre-se a uma diversidade de modos de vida e racionalidades produtivas, estas marcadas pelos limites e potencialidades da natureza e pelos sentidos do tempo (LEFF, 2000b).

\section{O vernáculo no caso do pantanal mato-grossense}

Na história da humanidade, a maior parte do espaço construído não foi projetado por profissionais ou mesmo estabelecido por cânones oficiais, mas foi antes de tudo uma expressão da tradição popular que, embora realizada por pessoas comuns, partia do mesmo impulso criativo que as obras de arte consideradas eruditas. Todos os ambientes construídos foram projetados no sentido de que englobassem as decisões e escolhas humanas à sua maneira específica de fazer as coisas. A esta arquitetura exercida por pessoas que constroem sem o fardo da solenidade oficial deuse o nome de vernacular; uma "arquitetura sem arquitetos" que ultimamente vem sendo valorizada em termos estéticos e metodológicos, embora não tenha sido regida pelos padrões tomados como civilizados ou acadêmicos, ou seja, sem ter havido uma vontade a priori de se fazer a "arte maior", tanto em espaços rurais quanto urbanos.

Etimologicamente a palavra "vernáculo" provém de vernae, que correspondia na Roma antiga, segundo Gianbattista Vico, citado por Rohde (1983), a tudo que se relacionava aos "servos nascidos em casa ou dos escravos que se faziam nas guerras". Assim, por exemplo, vernácula era a língua vulgar que se contrapunha à língua heróica ou poética. Com o passar do tempo - mas sempre mantendo seu caráter depreciativo - o termo começou a ser utilizado para designar uma arquitetura "caseira", não heróica, facilmente taxada de arcaica e excluída do universo de atuação oficial. O seu contraposto corresponderia à prática erudita, ou seja, aquela que obedeceria às regras, normas e cânones estabelecidos nas grandes Escolas de Belas-Artes ou Academias de Arquitetura, onde participa o arquiteto profissional, ou mesmo outra pessoa ligada ao sistema construtivo em voga (STROETER, 1986).

A história sempre privilegiou obras colossais, gigantescas ou singulares, considerando ideal somente a produção erudita e contrapondo-a a vernacular, que raramente foi registrada nas enciclopédias ou pela historiografia, tornando-as mutuamente exclusivas. Enquanto os edifícios das classes dominantes, tais como castelos, palácios e igrejas, são fartamente documentados, restaurados e preservados, as habitações simples e modestas do passado são difíceis de se encontrar, da mesma forma que não se destina muita atenção às constru- 
CASTELNOU, A. M. N. et al. Sustentabilidade socioambiental e diálogo de...

ções realizadas por povos primitivos, indígenas ou comunidades rurais. Contudo, o espaço vernáculo é a representação factual de uma técnica construtiva, de uma estrutura política e socioeconômica específica e de uma ideologia própria de determinada cultura, referindo-se à tradição local e à sabedoria popular.

Enquanto a arquitetura solene emana do poder e da autoridade legal, sendo praticada por profissionais diplomados, a vernacular expressa condições socioculturais específicas, padrões econômicos particulares e aspirações de uma população guiada por um ideal estético aceito por gerações. Se a prática oficial, segundo Rasmussen (1998), muitas vezes ignora os materiais, a energia, o seu contexto natural e sua própria sociedade, sendo fruto da divisão do trabalho e do saber científico, a vernácula segue um caminho árduo de tentativas e erros, de mudanças lentas, mas contínuas; e de um processo auto-adaptativo fundamentado na tradição. É fundamental perceber que a produção vernácula assenta-se no conhecimento de materiais e técnicas tradicionais; é normalmente autoconstruída - pelo clã, família ou grupo -; e revela um elevado respeito pelo artífice e pela qualidade (FATHY-SHEARER, 1986; sVENSSON, 1992). As estruturas vernaculares tendem a ser facilmente aprendidas e compreendidas, sendo feitas predominantemente com materiais locais. Ecologicamente, são apropriadas, pois se adaptam bem ao clima, ao relevo, à flora, à fauna e aos modos de vida locais.

As construções vernáculas nunca constrangem; passam para segundo plano no ambiente em vez de servirem de manifestações de design autoproclamatório. Têm uma escala humana (e), com freqüiência, o processo de construção é tão mais importante do que o produto acabado. Esta combinação de boa adaptação ecológica, proporção humana, habilidade e procura de qualidade, juntamente com uma forte preocupação com a decoração, a ornamentação e o embelezamento, leva a uma frugalidade sensual que resulta em autêntica elegância. (PAPANEK, 1998, p. 132-133)

Partindo das premissas expostas é que se propõe uma reflexão sobre o espaço vernáculo do Pantanal Matogrossense, mais especificamente do Mato Grosso do Sul. A imensa planície pantaneira, constituída por ecossistemas diversos, complexos e frágeis, clama por novos olhares sobre suas formas tradicionais de relações entre sociedade e natureza. Nas últimas décadas tem havido uma revalorização dessa região decorrente, sobretudo, da sua inclusão, em 1988, na Constituição Brasileira como Patrimônio Nacional da União. Mais recentemente, pelas suas características especiais e por sua importância para a humanidade, o Pantanal foi reconhecido pela UNESCO, em 2000, como Reserva da Biosfera.

O Pantanal Mato-grossense é uma das maiores extensões úmidas contínuas do planeta, localizada no centro da América do Sul. Sua área é de cerca de 138.183 km², com $65 \%$ de seu território no Estado de Mato Grosso do Sul e $35 \%$ no Mato Grosso, além de uma parcela menor que se estende em áreas da Bolívia e Paraguai. O clima predominante é quente e úmido no verão; e frio e seco no inverno. A região é uma planície aluvial influenciada por rios que drenam a Bacia do Alto Paraguai - BAP, onde se desenvolvem uma fauna e flora de rara beleza e abundância. Basicamente, reúne ecossistemas derivados de quatro grandes biomas: Amazônia, Cerrado, Chaco e Mata Atlântica. Estes se caracterizam por cerrados e cerradões sem alagamento periódico; por campos inundáveis; e por ambientes aquáticos, tais como lagoas de água doce ou salobra, rios, vazantes e corixos (cursos d'água intermitentes). Seus solos, em sua maior parte, são arenosos e suportam pastagens nativas utilizadas pelos herbívoros originais do local e pelo rebanho bovino. Devido à baixa declividade dessa planície, a água precipitada nas cabeceiras do rio Paraguai sofre escoamento lento, podendo levar mais de quatro meses para atravessar todo o Pantanal.

Como o Pantanal é suscetível a inundações periódicas com intensidade e duração variadas, Nogueira (1990) afirma ser nessa alternância do ciclo das águas e do estio que reside as condições de vida no Pantanal, sendo as enchentes cíclicas responsáveis pelo equilíbrio do sistema ecológico. No período das águas, as pastagens naturais são revigoradas proporcionando boas condições para a manutenção do rebanho bovino. Também nesse período são reabastecidos os corixos e a "baías" (imensas lagoas) da região. A abundância de água implica na abundância de vida animal e vegetal. Cursos d'água e lagoas servem de habitat para numerosas espécies de vegetação aquática, conhecidas regionalmente por aguapés e camalotes, chegando a constituir verdadeiras "ilhas" na imensidão hídrica. Por outro lado, a ictiofauna e a avifauna pantaneiras também são revigoradas pelo fenômeno das enchentes.

Entretanto, Nogueira assegura ser o Pantanal um sistema ecológico que não se completa apenas com o conjunto de uma avifauna e de uma flora variadíssimas, pois, para esta autora, "muito mais importante é o homem que nele vive tanto na condição de dono da terra, quanto na de va- 
queiro, empreiteiro, bagualeiro, garimpeiro, balseiro, pescador, etc."(NOGUEIRA, 1990, p. 12). Vê o pantaneiro como um ambientalista nato que, no convívio diário com o ambiente, aprendeu a fazer a leitura da natureza, a fim de captar suas mais sutis transformações. Além disso, por estar perfeitamente adaptado ao ambiente natural do Pantanal, pode-se considerar o homem local um "quase anfíbio" que tem se revelado como grande conhecedor do ambiente, desenvolvendo profundos saberes necessários à sua sobrevivência na região.

A exploração local, em grande parte, ainda acontece segundo antigos conceitos e tradições, considerados como responsáveis pela conservação do ambiente natural. Todavia, ultimamente, o Pantanal vem se comportando também como um grande depósito de sedimentos contaminados por mercúrio - derivados dos processos de mineração - e por resíduos de agrotóxicos - utilizados nas áreas de agricultura - atividades estas desenvolvidas nas regiões de planalto da BAP. Para contornar os graves problemas socioambientais pelos quais o Pantanal vem se sujeitando e, sobretudo, por considerar que cada sistema ambiental exige tratamento e soluções originais, adaptadas às peculiaridades locais, Nogueira (1990) preconiza a necessidade de absorção e assimilação da informação que o habitante local pode fornecer, mesmo que esta seja baseada puramente na observação empírica.

Para Leite (2000), a história da atividade da gente pantaneira, em destaque o peão de boiadeiro, o boiadeiro, o vaqueiro e o peão de fazenda, encontra-se imbricada com a pecuária extensiva, as grandes propriedades e as longas distâncias. Nogueira (1990) já havia destacado a peculiaridade dessa gente, que habita o extremo oeste brasileiro, vivendo num relativo isolamento, distante das grandes aglomerações urbanas, ao mesmo tempo em que tem como vizinhos próximos, bolivianos e paraguaios.

Originalmente ocupada por povoações indígenas, a região passou a receber elementos não-índios por volta do século XVI, quando espanhóis e portugueses, através dos caminhos desenhados pelo Rio Paraguai e seus afluentes, adentraram-se em seu território (COSTA, 1999). A partir de então, inúmeras etnias vêm construindo o que hoje pode ser denominado homem pantaneiro ou gente pantaneira ou, ainda, simplesmente pantaneiro. Trata-se de povos constituídos pela miscigenação de índios, europeus e africanos, que, para Antonio Cândido, constituiriam um "lençol de cultura caipira", esta ligada às formas de sociabilidade e subsistência que se apoiavam, por assim dizer, em soluções mínimas; apenas suficientes para manter a vida dos indivíduos (ROSSETO-BRASIL JÚNIOR, 2002).

Na busca de uma definição do "pantaneiro", Leite (2000) recorre à Nogueira que o identifica como o elemento nativo do Pantanal ou aquele que nele vive há mais de vinte anos, compartilhando hábitos e costumes típicos da região. Entretanto, Nogueira alerta para a necessidade de evitar assemelhar o pantaneiro ao caipira paulista, tendo em vista as diferentes formas de viver de cada um. Para esta autora, enquanto o caipira mantém traços de sedentarismo, o vaqueiro pantaneiro pode ser considerado, em certa medida, nômade por conta de sua atividade e, conseqüentemente, mais receptível às transformações (NOGUEIRA, citada por LEITE, 2000).

Sobre a organização do espaço vernáculo do Pantanal, excetuando o produzido pelos povos das nações indígenas de diferentes identidades étnicas que habitaram a região por centenas de anos, há que se destacar as produções implementadas a partir da fixação do homem branco ou mestiço, através da instalação das propriedades rurais ou fazendas. Observa-se que as terras pantaneiras, de acordo com Nogueira (1990), foram definitivamente povoadas pela gente não-índia somente após o declínio das atividades de mineração da região de Cuiabá, ao norte do Pantanal. Foi então em finais do século XVIII e início do século XIX que os campos nativos do Pantanal passam a serem vistos como propícios à criação de gado bovino, cedendo às pressões da expansão da pecuária brasileira.

Leite (2000) destaca que a implantação da pecuária e de outras atividades agrárias ocorreu inicialmente na região mineradora como produção complementar à extração de metais. O decréscimo desta atividade permitiu a ascensão mais intensa da pecuária, estendendo-se ao sul dessa área, alcançando as terras da planície panta-neira. Assim, o Pantanal foi sendo "repartido", no período colonial, em grandes latifúndios, inicialmente pelo regime de sesmarias, que restringia o direito às glebas de terras aos homens brancos, de "sangue puro", e dentre eles aos indivíduos que apresentassem real capacidade de fazê-las produzir, ou seja, aqueles que de antemão possuíssem escravos, gado e outros bens de produção (BANDUCCI, 1995).

Após a consolidação das fronteiras brasileiras e também em função da decadência da atividade mineradora, havia chegado o momento de implementar outra atividade econômica na região e, para tanto, no entendimento de Proença (1997), foram fundamentais quatro elementos: o desbravador-pioneiro, o vaqueiro, o cavalo e o boi. Para ele, os des- 
bravadores eram servidores do governo, ávidos por terra, descendentes de índios e bandeirantes mamelucos paulistas, geralmente antigos donos de lavras auríferas, à procura de outra ocupação. Já o vaqueiro ${ }^{5}$ originou-se do índio nativo, do negro escravo descendente de africanos que havia sido levado para a região aurífera, assim como do paraguaio, constituindo-se na mão de obra das fazendas pantaneiras.

Tanto o cavalo quanto o boi haviam sido introduzidos pelos aventureiros espanhóis ainda no século XVI, quando de suas incursões pela região. Sabe-se que esse gado bovino de origem européia, com o passar do tempo, foi adaptandose ao ambiente pantaneiro, tendo sofrido uma degeneração, transformando-se no chamado tucura. Mais tarde, houve inúmeras incursões de rebanhos bovinos, sobretudo zebuínos (de origem indiana), que hoje vem se constituir na raça nelore, prevalecente no rebanho pantaneiro da atualidade. Banducci (1995) afirma que, junto com os rebanhos bovinos vieram para o Pantanal, também, os desequilíbrios inerentes ao regime pastoril, reproduzindo na região as contradições e desigualdades próprias da estrutura fundiária brasileira. De todas as atividades desenvolvidas no Pantanal, a pecuária foi a mais determinante, tanto do ponto de vista econômico, quanto ocupacional. "Foi ela que realmente possibilitou a expansão humana na região, pois o gado, adaptando-se ao ambiente, permitiu que o vaqueiro penetrasse os lugares mais inóspitos e, apesar de todos os reveses, lá permanecesse e constituísse fazendas" (BANDUCCI, 1995, p. 24).

É correto afirmar que, na atualidade, a vasta região do Pantanal ainda se constitui basicamente por latifúndios. Além das fazendas de gado, o Pantanal comporta alguns núcleos urbanos, como as cidades de Corumbá, Miranda, Aquidauana e Coxim, no Mato Grosso do Sul; e Cáceres, Poconé e Barão de Melgaço, no Mato Grosso, entre outras. Banducci (1995) destaca a existência, também, de algumas colônias de pescadores, pequenas propriedades que vivem de agricultura, áreas de exploração turística, além de outras. Vale lembrar também a existência de algumas poucas aldeias indígenas. Tendo como referência as propriedades rurais estabelecidas no Pantanal da Nhecolândia, uma das dez subregiões do Pantanal Mato-grossense, localizada nos municípios de Corumbá e de Rio Verde (MS), Banducci (1995) descreve os núcleos humanos localizados em torno das sedes dessas propriedades. Nestes núcleos - denominados fazendas - encontram-se a casa grande (do proprietário), o galpão para os peões solteiros e as casas dos vaqueiros casados. Os demais personagens (roceiros, retireiros e empreiteiros) encontram-se dispersos pela propriedade. Para este autor, a casa grande costuma ser grande e confortável geralmente construída em alvenaria, com janelas e portas teladas para a proteção contra insetos, algumas dotadas de energia elétrica.

Esses núcleos humanos são estabelecidos em terrenos relativamente mais altos, visando a prevenção de enchentes, em geral próximos a uma baía. Antes da perfuração de poços e a instalação de bombas d'água, os habitantes locais utilizavam a água da baía ou rio próximos. Segundo Banducci, ainda hoje é comum observar "as mulheres dos peões recorrerem às baías para obter água para a cozinha, o banho e também para lavarem as roupas" (BANDUCCI, 1995, p. 35). Na sede da propriedade, encontrase também a oficina (onde se consertam as máquinas); o desencilhador - uma espécie de caramanchão onde os peões guardam os apetrechos de montaria e onde costumam reunir-se para conversar, tomar tereré e trabalhar o couro na produção de artefatos de arreamento -; o mangueiro, onde ordenham as vacas de leite; e um curral, onde o gado é trabalhado. Próximo à cozinha da casa grande, fica o açougue que armazena a carne do abate. A "carneação" (abate da rês bovina) é feita no "disco" de cimento (BANDUCCI, 1995).

Ainda segundo esse autor, o terreno arenoso que circunda a casa grande é chamado de praia. Nela ficam geralmente o pomar, a horta e os animais de criação, estes soltos ou presos em chiqueiros e galinheiros. $\mathrm{O}$ trabalhador responsável pela organização e conservação da "praia" é denominado praieiro. Um pouco mais afastadas da casa grande, e circundando a baía, encontram-se as moradias dos peões casados e o galpão, onde ficam os trabalhadores solteiros. As casas dos peões são construídas normalmente em alvenaria, mas esse padrão de moradia foge ao modelo tradicional, mais comum ao restante do Pantanal, onde há o predomínio de ranchos, feitos de carandá ou bocaiúva, palmeiras comuns

5 O vaqueiro é apresentado pelos autores consultados (BANDUCCI, 1995; LeITE, 2000; NogueIRA, 1999; ProENÇA, 1997) como categoria social predominante no Pantanal. Banducci (1995) ainda destaca a importância dos vaqueiros pelo fato deles se auto-definirem como pantaneiros, com base em uma história comum, em regras e redes de sociabilidade por eles tecidas através do tempo, pela convivência com um ambiente diferenciado e pelas formas de expressão do imaginário características de seu meio social e físico. 
no Pantanal, contendo apenas uma peça como sala e quarto, chamada camarinha, e, separado dela, a cozinha e, em alguns casos, um banheiro (fossa) ao fundo (BANDUCCI, 1995).

Para Banducci (1995), esses ranchos, verdadeiros exemplos de arquitetura vernácula, apesar de rústicos, possuem algumas vantagens em relação às edificações de alvenaria, pois, sendo mais frescos, permitem noites mais agradáveis no verão. Além disso, a localização da cozinha em separado do corpo da casa, permite maior arejamento e evita que a fumaça invada outros cômodos quando do entupimento das chaminés dos fogões à lenha. Nesses espaços, o piso é de chão batido e os móveis são quase inexistentes, havendo muita improvisação: os bancos substituem as cadeiras, os jiraus as mesas e, em muitos casos, as redes as camas. Manoel de Barros confirma este fato destacando que, em 1926, o antropólogo Claude Lévi-Strauss esteve no Pantanal e percebeu a pobreza dos móveis encontrados no interior das residências: "Dois ou três mochos na sala, arames de estender roupas nos quartos servindo de armário - e redes. Redes armadas por todos os cantos. Redes muitas de varandas artísticas, servindo de vasilhas de dormir e de sestear" (BARROS, 1992, p. 263).

O galpão, moradia dos peões solteiros, geralmente é feito de madeira ou alvenaria. Trata-se de construção simples, aberta em um dos lados, numa espécie de varanda onde os peões armam suas redes para dormir. Essa abertura é geralmente voltada para a direção norte, visando a proteção do vento sul que assola a região no inverno (BANDUCCI, 1995). Cumpre destacar que, ao posicionar a abertura do galpão e de demais edificações para o norte, aproveita-se a ventilação proveniente dessa direção, de onde, no verão, provêm os ventos predominantes.

Além desse núcleo básico, existem as roças, onde é praticada uma agricultura de subsistência para a propriedade; e os retiros, locais estratégicos, onde são construídos currais para trabalhar o gado mais disperso nas pastagens distantes da sede. Alguns retiros são habitados de forma permanente pelo trabalhador denominado retireiro, o qual tem "a função de controlar os rebanhos que se encontram naquela porção da propriedade" (BANDUCCI, 1995, p. 40).

Nogueira (2002), em consonância com Banducci (1995) lembra que, devido à dificuldade do transporte de material de construção, à falta de recursos econômicos e até à inexistência desses materiais, os fundadores das primeiras sedes das fazendas pantaneiras escolheram os ranchos como forma de moradia, estes geralmente construídos próximos a um rio. Bastante típicos no interior do país, tais obras não necessitam de equipamentos ou técnicas muito refinadas, nem de mão-de-obra especializada. O próprio dono, com a ajuda de uma ou duas pessoas, pode levantálas em poucos dias. Precisa-se em média de seis esteios de madeira de lei, caibros, ripas e material para cobertura, além de outros acessórios tirados da própria natureza (Figuras 1 e 2).

Os primeiros posseiros dos pantanais, confiantes de que estavam construindo abrigos provisórios, escolhiam o local mais apropriado para a sede e ali erguiam o rancho, um casarão, com paredes de pau-a-pique, barreadas. A cobertura era de capim sapé, de palha de acuri ou de telha de carandá, e, mais tarde seria fatalmente derrubado, para ceder lugar à construção de uma casa de material e, às vezes, uma mansão. (NOGUEIRA, 2002, p. 62)

Comuns no Pantanal, os ranchos de barrote, como são chamados, têm suas paredes construídas com barrotes de carandá ou de bocaiúva - palmeiras abundantes na região - servindo até hoje como abrigo de peões, já que, em alguns lugares, o patrão passou a habitar a casa grande ou sede composta por imponentes mansões com cômodos espaçosos, mobiliários requintados e utensílios modernos, ao modelo das habitações urbanas (Figuras 3 e 4). Há ainda outro tipo de construção, que seria o rancho beira-chão, na verdade, um abrigo precário, no qual se alojam os empreiteiros de cerca e agregados (Figuras 5 e 6). Também se tratam de obras de fácil execução, possuindo apenas dois esteios, apoiando a cumeeira, que sustenta as pontas mais finas dos caibros, enquanto as pontas grossas firmam-se no chão. Sobre os caibros colocam-se as ripas ou tabocas, que são amarradas por um cipó ou embira. Geralmente a cobertura, feita de palmas de acuri, babaçu ou bocaiúva, desce até o chão, servindo também de parede (NOGUEIRA, 2002).

Em um esforço para estabelecer a maneira como o pantaneiro concebe e relaciona-se com seu meio, Banducci (1995) assevera que o aprendizado mais importante inicia ainda na infância, quando os meninos acompanham os pais no trabalho campeiro.

Aí eles aprendem a "olhar" a natureza, a reconhecer suas diferentes formações vegetais e do espaço, a se localizar dentro dele e decodificar mensagens transmitidas 
CASTELNOU, A. M. N. et al. Sustentabilidade socioambiental e diálogo de...

por animais e plantas, os sons das matas e dos bichos, o comportamento do gado, das montarias, das caças e de outros animais silvestres. (BANDUCCI, 1995, p. 79)

Banducci concede detalhes do saber pantaneiro, no tocante às condições climáticas, saber este construído por meio da "escuta" e do "olhar", de sensações, que essa gente desenvolveu ao longo de várias gerações:

do comportamento inusitado dos animais os pantaneiros extraem informações valiosas sobre mudanças iminentes no clima e nas estações, permitindo-lhes prever com uma certa antecipação a chegada do frio ou do calor, das estações secas e chuvosas. Desse modo, no entender dos peões, quando o cavalo está tomando banho em baía e vaga-lume voando baixo, é anúncio de chuva. Se na beira da água o jacaré "urra", na certa é mudança de tempo. Macaco, quando grita muito à tardinha, ou urubu voando em círculos perto de casa, no outro dia é frio, mas, se cantou a seriema, sabe-se que está próximo de esquentar. O movimento das aves migratórias é também uma referência usual para demarcar os ciclos do tempo. (BANDUCCI, 1995, p. 81)

Outros saberes e "fazeres" pantaneiros têm destaque no trabalho de Banducci. Por exemplo, com os troncos e as folhas das palmeiras de carandá e de bocaiúva, a gente adulta pantaneira constrói suas habitações e as crianças, por sua vez, os transformam em cavalos de brinquedo.

Da inflorescência do carandá as mulheres fazem vassouras, enquanto que seu tronco é utilizado na fabricação de mangueiros e cercas, resistentes à água. Aroeira, piúva, cumbaru, vinhático, pequi entre outras madeiras da região também são utilizadas para a construção de cercados, cochos e porteiras. Como lenha preferem o angico, cuja casca, bem batida, é excelente para curtir couro de animais. O cambará e a chimbuva são os mais recomendados na construção de canoas, que podem ser fabricadas com piúva, mais pesada, além de outras madeiras. O capim carona é ideal para se fabricar colchões e as folhas do faveiro para encher o suador dos arreios. Os espinhos, como os de laranjeira, são usados para palitar os dentes ou para retirar estrepes dos dedos. Com a espinha de maminha fazem dados para jogar "bozó". (BANDUCCI, 1995, p. 82)

Esses exemplos elencados acima representam apenas parte do universo de saberes da gente pantaneira. Como a proposta deste artigo é a de concentrar a discussão em torno do conhecimento explícito na organização do espaço vernáculo, não cabe aqui a exposição de demais saberes, tais como aqueles ligados às propriedades medicinais de produtos vegetais $\mathrm{e}$ animais da região, a convivência com animais, além de outros aspectos culturais relacionados às representações de mundo do pantaneiro, incluindo a religiosidade e as crenças no sobrenatural, aspectos muito bem analisados por Banducci (1995).

Destacam-se ainda a singularidade e a riqueza do vocabulário da gente pantaneira, conforme exposto a seguir:

para se conhecer a cultura pantaneira há de se ir às raízes, é necessário que se vá ao chão para buscar a rusticidade e a simplicidade do homem do Pantanal. É preciso retirar as botas e atolar os pés na alma dos brejos e na relva das baías, porque ela não é coisa que se deixe aprisionar pelo frio entendimento de um estudioso de gabinete. É necessário seguir uma culatra e deixar a garganta secar de tanta poeira. Ver atar uma ligeira num chifre de bagual, olhar o vaqueiro trançar os tentos do laço ou fazer um tirador. É preciso pegar frieira nos vãos dos dedos dos pés e ter as palmas das mãos marcadas pela quentura dos telegramas. Permanecer numa roda de mate, sentado num toco, diante do galpão, escutando os "causos", enquanto a brisa vai se encarregando de trazer a manhã. É preciso sentir o vento sul bater no rosto, conhecer as fases da lua, saber olhar as horas pelo movimento do sol, dialogar com biguá pousado numa vara de poeira, chamar joão-debarro de amasso-barro, cão de cachorro, objetos pessoais de traias, par de roupa de pareio, mulher grávida de enxertada, café-da-manhã de quebra-torto. É preciso viver ou ter vivido no Pantanal, inserir-se à sua realidade, conhecê-lo de cabo a rabo. Assistir a um baile, presenciar a dança enquanto a luz da lamparina vai acompanhando a música, esquentando o ânimo da moçada, e projetando os corpos dos dançantes nas palhas dos acuris. (PROENÇA, 1997, p. 161-162) 
FIGURA 1 - CONSTRUÇÕES COM PAREDES EM PAU-A-PIQUE E COBERTURA EM CAPIM SAPÉ: ADEQUAÇÃO VERNÁCULA ÀS CONDICIONANTES DO MEIO NATURAL (FOTO DE MARIO RAMIRES E RAIMUNDO ALVES FILHO. NOGUEIRA, 2002)

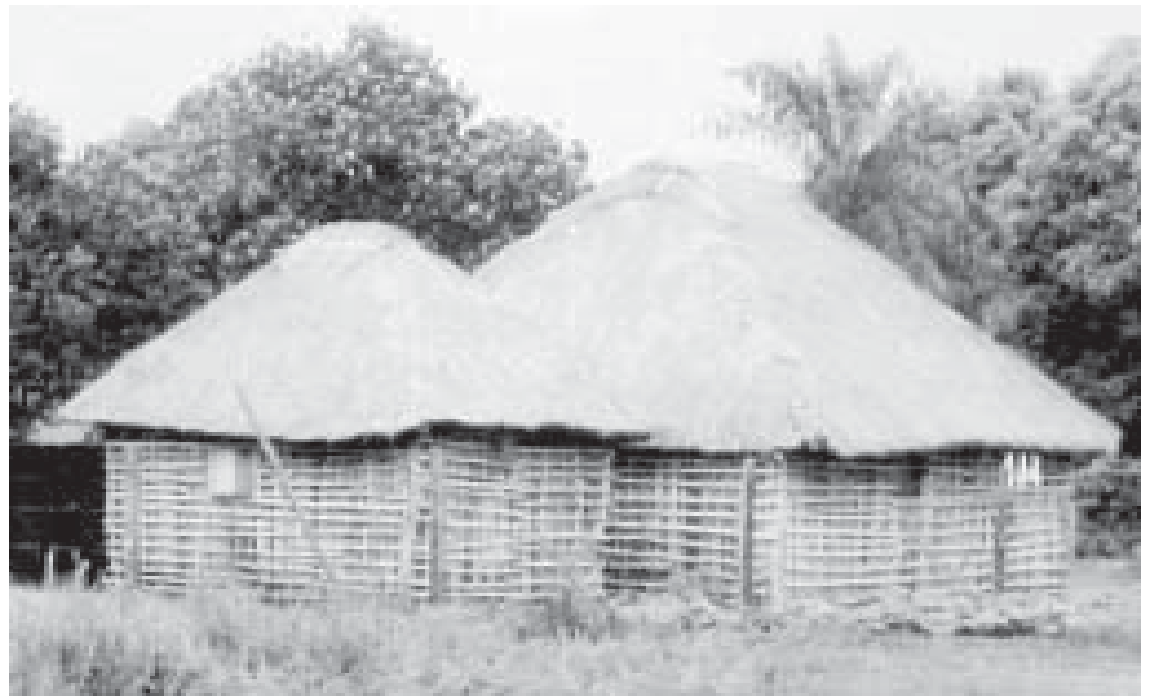

FIGURA 2 - ABRIGO VERNACULAR REALIZADO COM FOLHAS DE ACURI E COBERTURA EM PALHA: O PANTANEIRO ENCONTRA NO PRÓPRIO MEIO AS FORMAS DE PROTEÇÃO (FOTO DE MARIO RAMIRES E RAIMUNDO ALVES FILHO. NOGUEIRA, 2002)

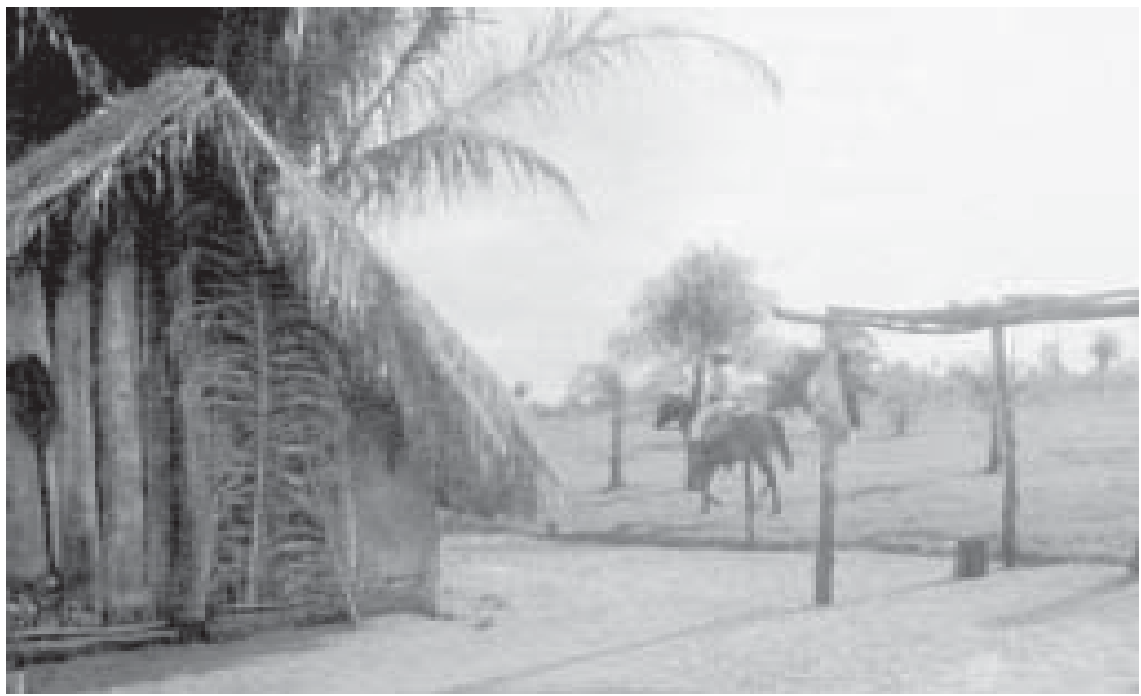


CASTELnOU, A. M. N. et al. Sustentabilidade socioambiental e diálogo de...

FIGURA 3 - RANCHO DE BARROTES QUE SERVE DE MORADIA AOS PEÕES: AMBIENTES ESPAÇOSOS SUBSTITUÍDOS POR PADRÕES URBANOS NO CASO DAS CASAS DOS PATRÕES (FOTO DE MARIO RAMIRES E RAIMUNDO ALVES FILHO. NOGUEIRA, 2002)

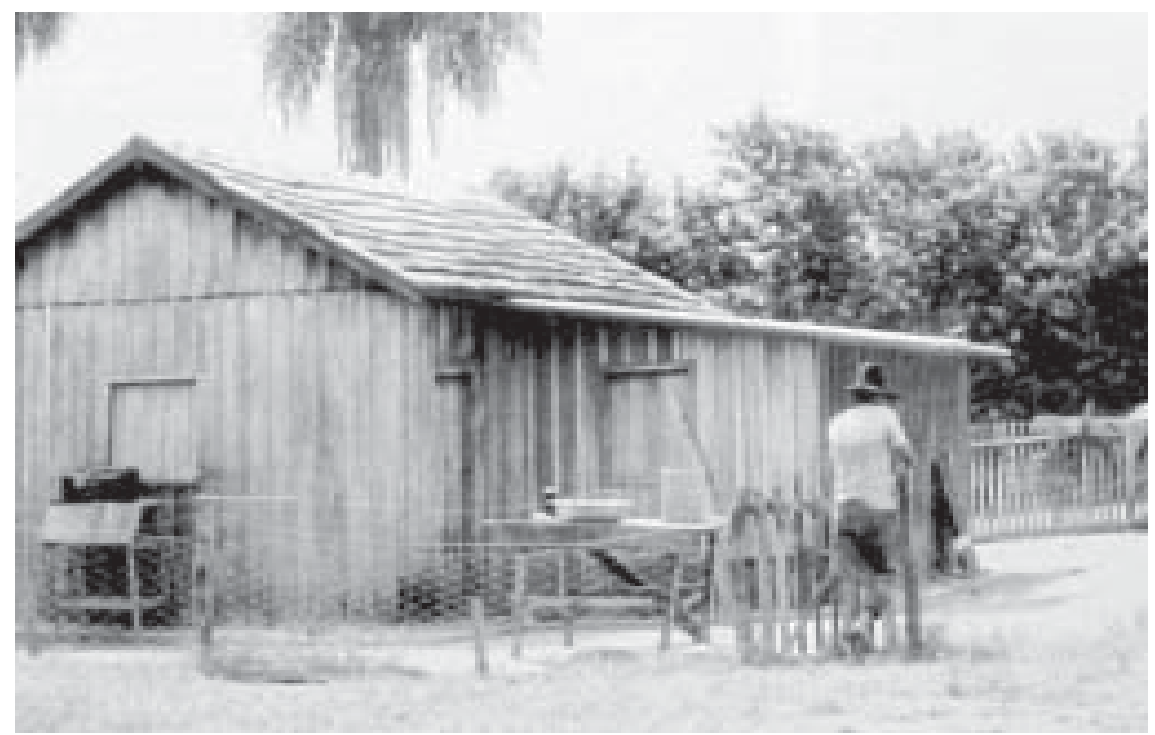

FIGURA 4 - HABITAÇÕES ESPONTÂNEAS EM PALAFITAS ÀS MARGENS DE CURSOS D'ÁGUA: ADAPTAÇÃO VERNACULAR ÀS CHEIAS SAZONAIS E AO MODO DE VIDA LOCAL (FOTO DE MARIO RAMIRES E RAIMUNDO ALVES FILHO. NOGUEIRA, 2002)

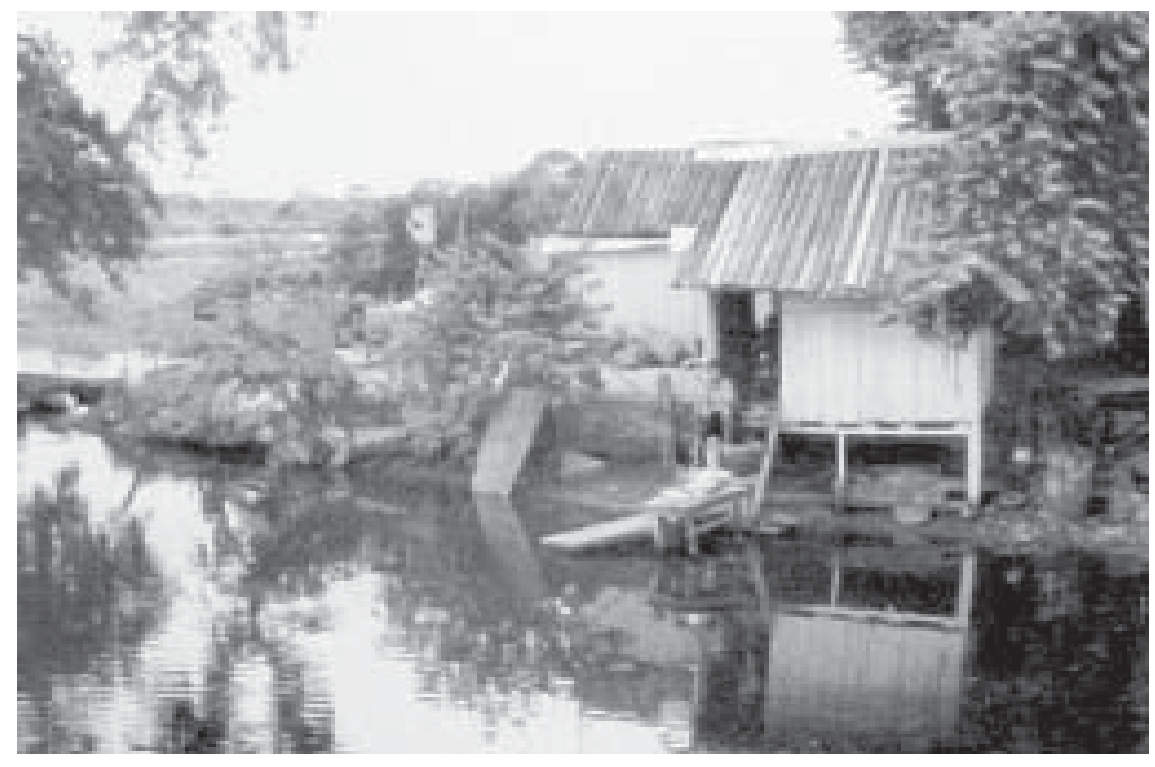


FIGURA 5 - RANCHO BEIRA-CHÃO COMPOSTO POR MATERIAIS NATURAIS E TÉCNICAS ARTESANAIS: PALMAS DE ACURI, BABAÇU OU BOCAIÚVA SERVINDO DE PAREDE E COBERTURA(FOTO DE MARIO RAMIRES E RAIMUNDO ALVES FILHO. NOGUEIRA, 2002)

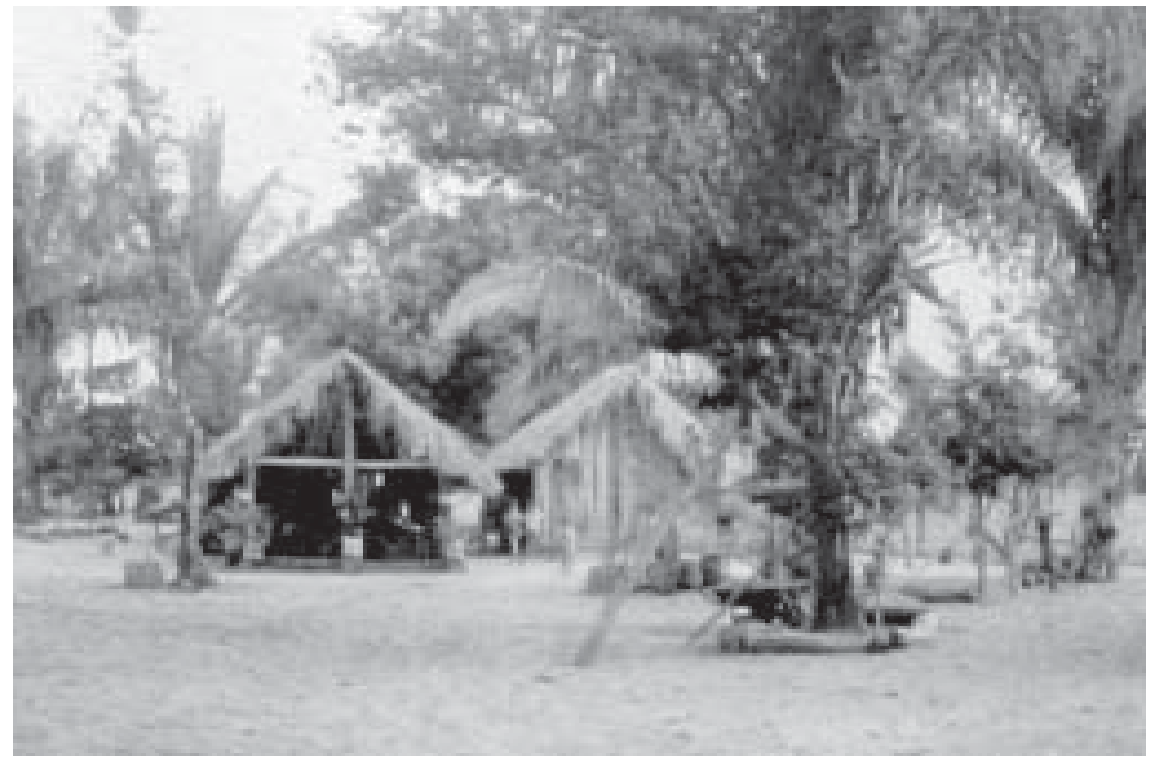

FIGURA 6 - HABITAÇÃO PANTANEIRACOMO SOLUÇÃO ESPACIAL VERNÁCULA: SABERES TRADICIONAIS COLOCADOS EM PROVA DIANTE DAS QUESTÕES SOCIOAMBIENTAIS (FOTO DE MARIO RAMIRES E RAIMUNDO ALVES FILHO. NOGUEIRA, 2002)

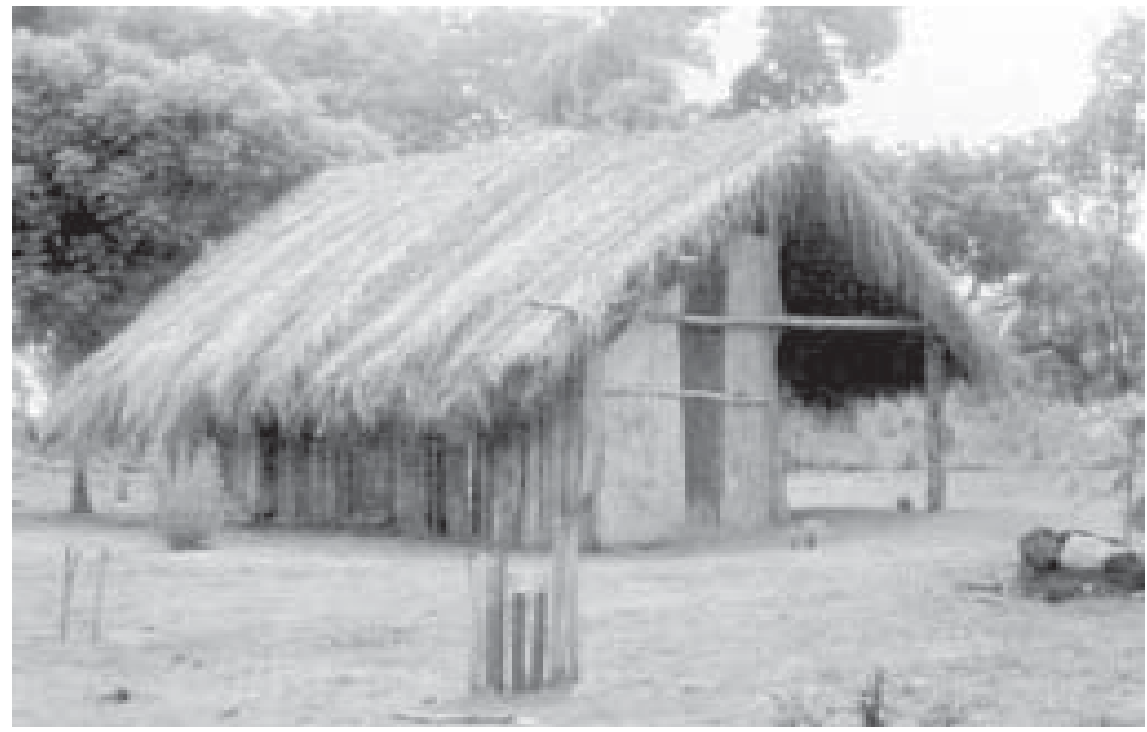


Para Rosseto-Brasil Júnior (2002), a simplicidade das formas de vida seria uma das características que acompanham as identidades dos que habitam as fazendas pantaneiras, independentemente da sua posição ou grupo social, sejam eles proprietários de terras, pequenos sitiantes, peões, vaqueiros ou capatazes. Esses autores afirmam que aos saberes do grupo que constitui os pantaneiros tradicionais é que deve ser atribuída a sustentabilidade da região. O sucessivo ritmo das águas nos pantanais conduziu à idéia de ciclos demarcados pelas épocas de cheia-vazante-seca, possibilitando o surgimento de saberes específicos que permitiram, por mais de três séculos, sua sobrevivência. Da mesma forma, a prática da pecuária como a principal atividade econômica também imprimiu marcas pouco nocivas às condições ecológicas locais. Destaca-se ainda que a natureza do Pantanal é percebida, pela gente pantaneira, como a grande responsável pela manutenção da atividade produtiva.

\section{Considerações finais}

Ao propor uma "nova aliança homem-natureza com o resgate da questão social", Enrique Leff aponta para uma revisão na postura de cientistas e técnicos diante da premente necessidade de estabelecer programas de planejamento e gestão socioambientais em áreas suscetíveis às interferências político-econômicas inerentes ao modo de agir das sociedades contemporâneas. Neste sentido evidencia-se aqui a possibilidade de travar um frutífero diálogo de saberes para se delinear estudos acerca da região pantaneira, os quais possam se constituir em preciosas contribuições para a construção de uma racionalidade ambiental capaz de interpretar a complexidade do Pantanal. Isto porque o saber ambiental levaria a um amálgama de saberes, desde os níveis mais altos de abstração conceitual até os níveis do saber prático e cotidiano, expressando-se e traduzindo-se em novas estratégias e práticas.

Leff (2001a) considera que esse saber, ao ser aplicado nos processos de gestão ambiental, levantaria a necessidade de elaborar indicadores interprocessuais capazes de analisar, avaliar e monitorar sistemas e processos ambientais complexos, tais como a qualidade de vida; as valorizações econômicas, culturais e sociais dos recursos; os impactos ambientais e as mudanças globais; o condicionamento ambiental da dinâmica demográfica e do espaço urbano-regional, nos quais intervêm processos de diversos níveis de materialidade e ordens de racionalidade.
Além disso, é facilmente verificável que as soluções vernaculares refletem as necessidades sociais, as faltas e os anseios das pessoas mais diretamente do que as estruturas concebidas por muitos arquitetos. Aqui, o meio ambiente desempenharia um papel fundamental. Condicionantes bioclimáticos e geográficos conduzem a diferentes - e, em alguns casos, similares - formas de construir em determinados locais, o que é também induzido por variados padrões de vida, percepções do espaço, estruturas agregacionais definidas pela cultura e pela tradição. Religião e magia, cosmologia e geomancia; a moralidade e, conseqüentemente, os costumes sexuais e tabus também influenciam diretamente as imagens de um espaço coletivo, as quais resultam em esquemas arquitetônicos vernáculos que poderiam ser úteis para o atual diálogo de saberes a que se propõe a questão ambiental.

A busca pela preservação dos recursos naturais, pela diminuição do impacto ambiental, pela produção alternativa de fontes energéticas, pela conservação da tradição e, no caso da arquitetura, pela aplicação de materiais e técnicas construtivas que não agridam o meio ambiente, trata-se de um dos desafios do mundo contemporâneo, o qual pode encontrar na experiência vernacular fortes pontos de contato e referência. Conforme Papanek (1998),

...é imenso o conteúdo didático das construções vernáculas, (mas é necessário) encontrar uma forma de o identificar e quais lições a aprender e porquê. Não se trata, como é óbvio, de uma tentativa de construir edifícios de escritórios com a forma de tipis de cimento armado com cinquienta andares nem de um convite à construção de edifícios governamentais no estilo das cabanas de troncos. Ao invés, é a esperança de que o único fato que separa as habitações vernáculas da maior parte das concebidas por arquitetos se relaciona com o conforto conforto visual e físico que apela diretamente para os nossos sentidos. (PAPANEK, 1998, p. 154)

Portanto, através do estudo das formas vernáculas de construir, de habitar e de produzir; enfim, do jeito de viver da gente pantaneira, que se tornará possível a criação de uma nova maneira de se pensar aquela realidade e, conseqüentemente, compreender o ambiente do Pantanal em sua grande diversidade e complexidade, promovendo uma nova consciência, a qual garanta a sustentabilidade socioambiental da região para o futuro. 
Em sua essência, o espaço construído pelo homem acaba refletindo sempre a estrutura e o estilo de vida de uma determinada sociedade, além de expressar uma adaptação inteligente de técnicas, materiais e formas às condições bioclimáticas e naturais de um lugar. Essa configuração espacial está, atualmente, bem mais próxima da prática vernacular que da oficial, esta bastante presa a modelos universalistas. Assim, o atual processo de conscientização ambiental vem cada vez mais valorizar o papel dos povos indígenas, dos extrativistas e dos remanescentes das comunidades tradicionais, os quais passaram a ser reconhecidos não como meras testemunhas do passado, mas que, por sua vivência e através do seu modo de produção, têm muito a ensinar sobre o que é verdadeiramente uma sociedade sustentável.

Ao se projetar uma habitação, dever-se-ia considerar fatores como a orientação para montanhas, vales e rios; a direção do Sol; os ventos predominantes; os esquemas de precipitação e de inundação; e a temperatura. Isto é uma prática corrente na esfera vernacular. O emprego de coberturas duplas, galerias externas, paredes baixas e elementos vazados, bastante típicos em regiões quentes como o Pantanal, poderia ser aplicado como exemplo pela arquitetura oficial, assim como as estrutura dos telhados e as duplas paredes de tijolos ou pedras usadas nas terras altas da Grécia e nas habitações das regiões montanhosas de alguns lugares da América Latina. Estes deveriam ser vistos como alternativas ao ar-condicionado ou ao consumo excessivo de energia para aquecimento. Assim, entender o espaço de vivência da gente pantaneira seria o primeiro passo em direção a uma verdadeira transformação no modo de conceber o desenvolvimento daquela região, tendo em vista a sua preservação socioambiental.

Paralelamente, árvores e arbustos poderiam ser plantados como pára-ventos e orientadores das correntes de ar, mais uma vez poupando a energia do condicionamento artificial, assim como contribuindo como eficientes barreiras sonoras e filtros da poluição do ar, além de promoverem uma sensível melhoria da sensação térmica nas grandes cidades. Vestíbulos poderiam servir de câmaras de ar tanto no inverno como no verão; aberturas zenitais, sheds e pátios internos poderiam favorecer a iluminação natural dos ambientes; e os telhados com beirais amplos garantiriam a proteção adequada a chuvas torrenciais, além de proporcionarem interiores mais orgânicos e equilibrados. Da mesma forma, as técnicas e os métodos de construção deveriam ser benignos para o meio ambiente: sempre que possível, deveriam ser usados materiais naturais e de preferência locais.

Se acreditarmos que a interdisciplinaridade, no âmbito do meio ambiente e desenvolvimento, é uma ação do conhecimento que consistiria em confrontar saberes, cuja finalidade é alcançar outro saber, mais complexo e integral, diferente daquele que seria efetuado, caso não existisse o encontro de diferentes disciplinas (FLORIANI, 2000), o diálogo entre os conhecimentos oficiais e vernaculares é fundamental. Somente assim se tornaria possível traduzir na prática atual, de forma efetiva, a complexidade das interações entre as sociedades humanas e o ambiente natural. Além do mais, os fazeres vernáculo e erudito não são modos excludentes de agir sobre o meio: ambos se retroalimentam e se inter-influenciam, do mesmo modo que tradição e invenção são faces de uma mesma moeda (MAHFUZ, 1984, p. 1987).

Contudo, é importante lembrar que a interdisciplinaridade não existe de antemão: ela é constitutiva e constituinte do processo interdisciplinar; produto de uma associação disciplinar (FLORIANI, 2000). A ação interdisciplinar ocorreria em regiões de fronteira de representação da realidade e se ampliaria pela ação combinada das disciplinas presentes em um programa de ação. A fronteira não é o limite intransponível: seria, porém o limite da diferenciação que permite, ao mesmo tempo, ajustar-se entre diferentes domínios e separar-se das especificidades da realidade captadas pelos procedimentos disciplinares, para se fazer uma nova síntese, integradora, da multiplicidade do real (FLORIANI, 2000).

Desse modo, a interdisciplinaridade é uma chamada para a complexidade, de forma a restabelecer as interdependências e inter-relações entre processos de diferentes ordens de materialidade e racionalidade, internalizando as externalidades dos processos excluídos dos núcleos de racionalidade que organizariam os objetos de conhecimento de todas as ciências (LEFF, 2000a). Busca-se assim uma "retotalização" do conhecimento - uma "completude" até então não alcançada pelo projeto de cientificidade que buscava a unidade de conhecimento, a objetividade e o controle da natureza -, o qual terminou fraturado em vários saberes científicos; ou ainda subjugando os saberes "não científicos", tradicionais e vernáculos. A arquitetura deste novo milênio precisa reincorporar conceitos e práticas que a conduzam para sua re-harmonização com o meio ambiente, adotando uma postura que reconheça a finitude, assim como a "renovabilidade", dos recursos naturais; além de 
uma metodologia interdisciplinar que possibilite um diálogo de saberes e uma nova racionalidade. Essa arquitetura ou eco-arquitetura pode vir a ser designada por vários termos, mas o fundamental não é isso: é que ela represente a constituição de um profundo saber ambiental. Em paralelo a todos os níveis de vivência humana, este levaria a uma resignificação dos sentidos existenciais e a uma reconfiguração das identidades individuais e coletivas, ao mesmo tempo em que possibilitaria a reconstrução do mundo objetivo. Equivaleria, enfim, ao rompimento com o conhecimento universal e disciplinar que implanta o regime de dominação da natureza através da ciência e que se situa acima das identidades culturais, em direção a uma verdadeira hibridação entre ciências, tecnologias e saberes.

A região pantaneira, apesar de tradicionalmente ter sido praticada a atividade criatória - a pecuária extensiva de bovinos -, mais recentemente, dada a sua ampla projeção na mídia, vem despontando como um "paraíso ecológico" destinado às atividades turísticas. Aliás, tal atividade, na modalidade do ecoturismo, é defendida por muitos como a única alternativa econômica possível de conciliar desenvolvimento e preservação do Pantanal. Contudo, deve-se tomar o cuidado com os riscos da estereotipação, quando aparecem fórmulas e modelos que acabam conduzindo à produção de "não-lugares", ou seja, espaços arquitetônicos sem identidade, calcados em imagens fantasiosas criadas para atrair visitantes alheios às verdadeiras características e peculiaridades da região, em uma atitude de mascaramento e pura distorção do que é realmente o ambiente da gente pantaneira.

\section{Glossário}

Adobe: Termo originário do árabe $a t-o b$, que designa um tijolo rudimentar de terra misturada com palha, que é secado ao sol e utilizado para a construção em várias regiões do mundo.

Barrote(s): Peça de madeira ou de palmeiras, como carandá, bocaiúva e bacuri, usada para segurar as paredes de um rancho. Trata-se de uma viga de seção reduzida também utilizada na sustentação de tetos e assoalhos.

$\operatorname{Bioma}(s)$ : Conjunto de formas de vida (animais e vegetais) que ocupam determinada área natural, sob influência de um mesmo tipo de clima, como, por exemplo, a estepe, a savana, a floresta, o deserto, o litoral, as águas fluviais, as águas salobras, etc.
Por fim, acredita-se que a constituição da racionalidade ambiental depende da valorização da natureza e da cultura, da atualização e reconfiguração das identidades, e da emergência de novos atores sociais. Essa nova forma de pensar, baseada nos potenciais ecológicos da natureza e nos significados culturais dos povos; voltada à sustentabilidade a partir das especificidades dos ecossistemas, da diversidade cultural e da autonomia das populações locais, corresponderia a uma nova forma de fazer e, conseqüentemente, produzir o espaço; na verdade, o ponto de contato, concreto e real, simbólico e ideológico, na relação sociedade-natureza. E provavelmente, a partir das sutis lições do vernáculo, aprenderíamos como descobrir as formas do futuro através da sabedoria do passado.

E, retomando a célebre asserção do poeta e pensador Manoel de Barros de que "o Pantanal é obra inacabada. E toda obra inacabada abrange mistérios, abrange prenúncios, abrange duendes (...)", deveríamos admitir que existe ali uma dimensão além do alcance de nossa vã capacidade de compreensão. Construída sob os auspícios da raciona-lidade instrumental ocidental, esta nem sempre permite ser "vista" além do ilusório. O Pantanal abrange necessidades de implementação de políticas que redirecionem o processo vigente de organização de seus espaços ecológico, geográfico, cultural, político e econômico, revertendo ações predatórias; e promovendo, por meio de uma gestão alicerçada na racionalidade ambiental, um profícuo diálogo de saberes com a comunidade local.

Cânon(es): Palavra de origem grega (kanon; regra), que designa o conjunto de normas que fixam a constituição de uma disciplina, sistema ou código estético, reconhecido por academia.

Caibro(s): Termo originário do latim capreu, de caprea (cabra montês), utilizado para designar cada uma das peças de madeira de seção retangular, que vão da cumeeira ao frechal de um telhado e sobre os quais se assentam as ripas.

Cerrado: Formação vegetal típica do planalto central brasileiro, cuja extensão estima-se ser de $2.000 .000 \mathrm{~km}^{2}$, caracterizando-se por dois estratos; um herbáceo, formado por gramíneas que recobrem inteiramente o solo ou se apre- 
sentam em tufos, com altura média de $50 \mathrm{~cm}$; e outro, arbóreo-arbustivo, com árvores esparsas de médio e pequeno portes.

Cerradão: Termo utilizado para designar, na Região Centro-Oeste, a vegetação de transição entre mata e campo cerrado, sendo esta constituída de árvores baixas, que não ultrapassam $15 \mathrm{~m}$ de altura, e grande número de arbustos, lianas e gramíneas. Apresenta espécies comuns à mata (paineira, aroeira, jacarandá, óleo-vermelho) e outras típicas do cerrado (pau-terra, pau-santo e pequi).

Chaco: Vasta região de planícies da América do Sul, limitada pelos rios Paraguai e Paraná, a leste; pelos Andes, a oeste; pelo rio Salado, ao sul; e pelos lhanos de Chiquitos, já na Bolívia, ao norte, sendo coberta por savanas e estepes, com clima de tropical a subtropical, mais seco ao norte e a oeste, onde atinge a semi-aridez.

Cipó: Variação de icipó, de origem tupi, que designa as plantas sarmentosas ou trepadeiras, em geral nascidas em mata virgem, que dependem das árvores e nelas se traçam. Também pode ser usada como sinônimo de vara ou chicote.

Cumeeira: Popularmente conhecida como cumieira, consiste na parte superior de um madeiramento sobre o qual se apóiam os caibros que constituem uma cobertura. Considera-se portanto a parte mais alta de um telhado, onde se encontram as superfícies inclinadas (águas).

Embira: Palavra proveniente do tupi e'bira, que denomina arbustos do gênero Daphnopsis, da família das timeleáceas, constituindo-se de uma fibra usada como cordel.

\section{REFERÊECIAS}

BANDUCCI JÚNIOR, A. Sociedade e natureza no pensamento pantaneiro: representação de mundo e o sobrenatural entre os peões das fazendas de gado na "Nhecolândia" (Corumbá-MS). São Paulo, 1995. Dissertação (Mestrado) - Programa de PósGraduação em Antropologia Social - Universidade de São Paulo. 200 p.

DE BARROS, M. Gramática expositiva do chão (Poesia quase toda). 2. ed. São Paulo: Civilização Brasileira, 1992. 343p.

BECK, U. Risk society: towards a new modernity. London: Sage Publications, 1992. 289p.
Geomancia: Termo que literalmente significa "adivinhação (manteia) pela terra (geo)", corresponde a um método de consulta que consiste em traçar pontos sobre uma superfície e, ao se jogar ao acaso pedregulhos, deduzir, segundo as figuras, as respostas às suas questões.

Holismo: Doutrina epistemológica defendida, sobretudo por Pierre Duhem (1861-1916), segundo a qual nunca é um enunciado científico isolado, mas o corpo inteiro da ciência, que se confronta com o veredicto da experiência, ligando-se a um processo de síntese criadora.

Pau-a-Pique: Parede feita de ripas ou varas entrecruzadas e barro, geralmente associada à taipa. No Nordeste brasileiro, designa a cerca ou curral feito de esteios fortes fincados a curta distância uns dos outros.

Sapé: Também conhecido como sapê, provém do tupi ssa'pé, que significa "o que ilumina" e designa comumente várias plantas gramináceas, entre as quais a Imperata brasiliensis (capim-sapé), cujos colmos servem para a fabricação de vassouras e coberturas de choupanas.

Sesmarias: Termo que significa a terra ou região que se encontra abandonada. No Brasil, passou a designar a terra inculta que os reis de Portugal davam a sesmeiros para serem cultivadas e tornarem assim produtivas.

Shed $(s)$ : Palavra de origem inglesa que se refere a um tipo de cobertura de várias águas, cujo perfil lembra dentes de serra, sendo uma superfície opaca e outra envidraçada.

Tipi(s): Tenda cônica dos índios norte-americanos, originalmente denominada teepee, feita de galhos cruzados e recoberta com pele de bisão.

VON BERTALANFFY, L. General system theory: fundations and development applications. New York: George Braziller, 1976. 296p.

COSTA, M. F. A história de um país inexistente: Pantanal entre os séculos XVI e XVIII. São Paulo: Estação Liberdade, 1999.

FATHY, H.; SHEARER, W. Natural energy and venacular architecture. Chicago: Chicago University Press, 1986. 243p.

FLORIANI, D. Interdisciplinariedad: teoría y práctica de la investigación y la enseñanza. Form Amb. [S.I.], n. 10. p. 23, 1998. 
CASTElnOU, A. M. N. et al. Sustentabilidade socioambiental e diálogo de...

. Marcos conceituais para o desenvolvimento da interdisciplinaridade. In: PHILIPPI JUNIOR, A.; TUCCI, C. E. M.; HOGAN, D. J.; NAVEGANTES, R. Interdisciplinaridade em ciências ambientais. São Paulo: Signus Editora, 2000. 318p.

. A complexidade ambiental nos convida a dialogar com as incertezas da modernidade. Curitiba: Ed. UFPR, 2001. (Desenvolvimento e meio ambiente; n. 4).

lo.

. Conhecimento, meio ambiente e globalização. No pre-

FOUCAULT, M. A arqueologia do saber. 6. ed. São Paulo: Forense Universitária, 2000. 239p.

GONÇALVES, C. W. P. Meio ambiente, ciência e poder: diálogo de diferentes matrizes de racionalidade. In: SorRENTINo, M. (Coord.) Ambientalismo e participação na contemporaneidade. São Paulo: EDUC/FAPESP, 2001. p. 135-161.

LEFF, E. Sociologia y ambiente: formación socioecnómica, racionalidad ambiental y transformaciones del conocimiento. In: LEFF, E.; GÁRCIA, R.; GUTMAN, P.; TOLEDO, V.; VESSURI, H.M.C.; FERNÁNDEZ, R.; BRAÑES, R. (Coord.) Ciências sociales y formación ambiental. Barcelona: Gedisa, 1994.

LEFF, E. Complexidade, interdisciplinaridade e saber ambiental. In: PHILIPPI JUNIOR, A.; TUCCI, C. E. M.; HOGAN, D. J.; NAVEGANTES, R. (Ed.) Interdisciplinaridade em ciências ambientais. São Paulo: Signus, 2000a. 318p.

LEFF, E. Ecologia, capital e cultura: racionalidade ambiental, democracia participativa e desenvolvimento sustentável. Blumenau: FURB, 2000b. 381p.

LEFF, E. Espacio, lugar y tiempo: la reapropriación social de la naturaleza y la construcción local de la racionalidad ambiental. Curitiba: Ed. Ufpr, 2000c. 108p. (Desenvolvimento e Meio Ambiente; n. 1)

LEFF, E. EPISTEMOLOGIA AMBIENTAL. São Paulo: Cortez, 2001a.

. Saber ambiental: sustentabilidade, racionalidade, complexidade, poder. Petrópolis: Vozes, 2001b. 343p.

LEFF, E.; ARGUETA, A.; BOEGE, E.; PORTO GONÇALVES, C. W. Más allá del desarollo sostenible: la construcción de una racionalidad ambiental para sustentabilidad - una visión desde América Latina. In: LEFF, E.; EZCURRA, E.; PISANTY, I.; LANKAO, P. R. (Coord.) La transición hacia el desarollo sustentable: perspectivas de América Latina y el Caribe. México: [s.n.], 2002. p.479-578.
LEITE, E. F. Marchas na história: comitivas, condutores e peões-boiadeiros na águas de Xarayes. Assis, 2000. Tese (Doutorado) - Faculdade de Ciências e Letras da Universidade Estadual Paulista "Júlio de Mesquita Filho". 281p.

LÉVI-STRAUSS, C. Structuralism and ecology. Social Science Information. [S.I.], v.12., n. 1, p. 7-23, 1972.

MAHFUZ, E. Nada provém do nada: a produção da arquitetura vista como transformação de conhecimento. Revista Projeto. São Paulo, n. 69, p. 89-95, nov. 1984.

. Tradição \& invenção: uma dialética fundamental. Revista AU - Arquitetura e Urbanismo. São Paulo, n. 12, ano 3, p.70-4, jun./jul. 1987.

MENDONÇA, F. Geografia e meio ambiente. São Paulo: Contexto, 1993.

MORIN, E. Le paradigme perdu: la nature humaine. Paris: Editions Du Seuil, 1973. 246p.

Os sete saberes necessários à educação do futuro. Brasília: Unesco, 2000.

Ciência com consciência. 5. ed. Rio de Janeiro: Bertrand, 2001.

NOGUEIRA, A. X. O que é Pantanal. São Paulo: Brasiliense, 1990. 77p.

Pantanal: homem e cultura. Campo Grande: Universidade Federal do Mato Grosso do Sul - UFMS, 2002. 156p.

PAPANEK, V. Arquitetura e design: ecologia e ética. Lisboa: Edições 70, 1998. 280p.

PITT, D. Towards ethnoconservation. In: MCNEELY, J.; PITT, D. Culture and conservation: the human dimension in environmental planning. IUCN: Croom Helm, 1985.

PRIGOGINE, I. O fim das certezas: o tempo, caos e as leis da natureza. São Paulo: Universidade Estadual Paulista - Unesp, 1996. 200p.

PROENÇA, A. C. Pantanal: gente, tradição e história. Campo Grande: Editora da UFMS, 1997. 168p.

RAYNAUT, C. Processo de construção de um programa interdisciplinar de pesquisa no quadro do doutorado em meio ambiente e desenvolvimento (MAD/UFPR).. Curitiba: Ed. Ufpr, 1996. 174p. (Desenvolvimento e Meio Ambiente; n. 3).

RASMUSSEN, S. E. Arquitetura vivenciada. 2. ed. São Paulo: Martins Fontes, 1998. 232p. 
CASTElnOU, A. M. N. et al. Sustentabilidade socioambiental e diálogo de...

RODRIGUES, A. M. Desenvolvimento sustentável e atividade turística. In: SERRANO, C. et al. (Org.). Olhares contemporâneos sobre o turismo. São Paulo: Papirus, 2000. p.171-87.

ROHDE, G. M. Arquitetura espontânea no Rio Grande do Sul. In: Bertussi, P. I. et al. A arquitetura no Rio Grande do Sul. Porto Alegre: Mercado Aberto, 1983. 106p.

ROSSETO, O. C.; Brasil Júnior, A. C. P. A dimensão dos aspectos culturais na construção das paisagens sustentáveis das áreas alagadiças: Pantanal do Pe. Inácio - Jauru, Cáceres MT. In: Encontro da ANPPAS, 1. , 2002, Indaiatuba.

STROETER, J. R. Arquitetura \& teorias. São Paulo: Nobel, 1986. 210p.

SVENSSON, F. Arquitetura, criação e necessidade. Brasília: Universidade de Brasília - UnB, 1992. 204p.

UNESCO. Universities and environmetal education. Paris:
United Nations for Education, Science and Culture Organization - UNESCO, 1986.

WILSON, E. O. Sociobiology: the new synthesis. Cambridge: Harvard University Press, 1975. 697p.

WINES, J. Green architecture. Köln: Benedikt Taschen, 2000. 240p.

SVENSSON, F. Arquitetura, criação e necessidade. Brasília: Universidade de Brasília - UnB, 1992. 204p.

UNESCO. Universities and environmetal education. Paris: United Nations for Education, Science and Culture Organization - UnESCO, 1986.

WILSON, E. O. Sociobiology: the new synthesis. Cambridge: Harvard University Press, 1975. 697p.

WINES, J. Green architecture. Köln: Benedikt Taschen, 2000. 240p. 